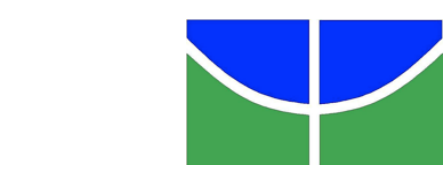

Universidade de Brasília - UnB

Faculdade de Direito

Curso de Graduação

\title{
A INTERVENÇÃO DO ESTADO NA ECONOMIA SEGUNDO A CONSTITUIÇÃO DE 1988: APLICAÇÃO À ATIVIDADE DO BNDES
}

SERGIO MURILO GONÇALVES MARELLO

Brasília, dezembro de 2011. 


\section{A INTERVENÇÃO DO ESTADO NA ECONOMIA SEGUNDO A CONSTITUIÇÃO DE 1988: APLICAÇÃO À ATIVIDADE DO BNDES}

\section{SERGIO MURILO GONÇALVES MARELLO}

Monografia apresentada como requisito à obtenção do grau de bacharel em Direito pela Universidade de Brasília - UnB, elaborada sob orientação do Prof. Othon de Azevedo Lopes.

Brasília, dezembro de 2011. 
FOLHA DE APROVAÇÃO

TÍTULO DA MONOGRAFIA: A INTERVENÇÃO DO ESTADO NA ECONOMIA SEGUNDO A CONSTITUIÇÃO DE 1988: APLICAÇÃO Á ATIVIDADE DO BNDES

ALUNO: SERGIO MURILO GONÇALVES MARELLO

MATRÍCULA: 07/38247

Monografia apresentada à Faculdade de Direito (FD) da Universidade de Brasília (UnB) como requisito para a obtenção do grau de Bacharel em Direito.

\section{BANCA EXAMINADORA}

Professor Orientador: Othon de Azevedo Lopes, Professor da Faculdade de Direito da UnB (FD) Doutor em Direito pela PUC-SP Mestre em Direito (UnB)

Membro da Banca: Ricardo Barretto de Andrade, Mestrando pela Faculdade de Direito da UnB

Membro da Banca: Igor Ascarelli Castro de Andrade, Doutorando pela Faculdade de Direito da $\mathrm{UnB}$ 
Agradecimentos

Agradeço a Deus, meus pais, minha namorada, familiares, amigos $e$ professores, por todas as contribuições. 


\section{RESUMO}

A finalidade estatal não pode ser outra, senão a garantia e proteção da existência (digna) de seus governados, portanto, a defesa e manutenção de uma Economia próspera e estável, que preze pela igualdade material para que se atinja a justiça social, é meio idôneo para que o Estado atinja essa e outras finalidades. A presente pesquisa tratará d a intervenção estatal na economia. $\mathrm{O}$ tema é o ponto central da disciplina do Direito Econômico. Na Constituição de 1988, com a passagem das atividades, antes públicas, para o setor privado tornou imprescindível a atuação regulatória, fiscalizatória e de planejamento pelo Estado. O Poder Público deixou de interferir na Economia nos moldes do Estado Social, e passou a adotar os intervencionismos próprios do Estado Regulador. Nossa Constituição garante ampla liberdade aos particulares para empreenderem atividades econômicas, contudo condiciona a ordem econômica que se instala (mundo do ser), aos princípios constitucionais, condicionando a atividade econômica, em regra, por meio da regulação em Ordem Econômica Constitucional (mundo do dever ser). Desse modo, tanto o Estado como os particulares estão adstritos a esses princípios constitucionais. Cabendo ao Estado intervir para garantir a observância desses princípios.

Palavras Chave: Ordem Econômica, Constituição de 1988, Intervenção, Estado, Economia, BNDES. 


\begin{abstract}
The state purpose cannot be other than the guarantee and protection of its citizens' life, therefore, the defense and maintenance of a prosperous and stable economy, which stands for material equality for the achievement of social justice, it's a suitable way for the state to achieve this and other purposes. This research will focus on state intervention in the economy. The theme focuses on Economic Law. The 1988 Constitution established the passage of the activities before public to the private sector, now the state has a crucial regulatory action, surveillance and planning the economy. The Government failed to intervene in the economy along the lines of the Welfare State, and became interventionist by regulation. Nowadays, our constitution guarantees individual freedom to undertake economic activities, however, the economic constitution order establishes several constitutional principles that should guide the economic activity, as a rule. Thus, both the State and individuals are assigned to these constitutional principles. Fitting the state intervene to ensure compliance with these principles.
\end{abstract}

Keywords: Economic Order, the 1988 Constitution, Intervention, State, Economy, BNDES. 


\section{SUMÁRIO}

1. Introdução

2. Conceitos Fundamentais 4

2.1 Economia 5

2.2 Direito 6

2.3 Direito Econômico e Estado 9

2.4 Estado 10

2.5 Estado de Direito 14

3 Do Estado Liberal aos dias atuais 17

3.1 Estado Liberal 18

3.2 A crise do liberalismo - Estado Intervencionista 20

3.2.1 Estado Intervencionista Econômico 22

3.2.2 Estado Intervencionista Social - Estado do Bem Estar Social 23

3.3 Estado Regulador 24

4 A Constituição de 1988 27

4.1 Histórico Nacional 27

4.2 Ordem Econômica na Constituição de 1988 31

4.3 Princípios Constitucionais 37

4.3.1 Princípio da Livre Iniciativa 39

4.3.2 Princípio da Livre Concorrência 45

4.3.3 Princípio da Função Social da Propriedade 49 
5 A Intervenção do Estado na Economia: Análise da Atuação do BNDES 56

5.1 A Intervenção estatal na economia 56

5.1.1 Intervenção Indireta 56

5.1.2 Intervenção Direta 63

5.2 O BNDES 65

5.2.1 História e importância 65

5.2.2 Fins e Função Social do Banco de Desenvolvimento 67

5.2.3 Atuação do BNDES e a Liberdade Econômica 71

6 Conclusão 75

7 Referências Bibliográficas 79 


\section{Introdução}

O Direito Econômico, como disciplina jurídica, é ramo relativamente novo. Isso

se dá, como será explicado no presente trabalho, em razão de uma série de fatores históricos que anteriormente não favoreceram o surgimento de normas jurídicas que regulamentassem a atividade econômica.

As relações econômicas ganham destaque, para este trabalho, a partir do advento da Idade Moderna, simbolizada pela Revolução Francesa, na qual se concretizaram as demandas do movimento revolucionário liberal - liderado pela classe burguesa, sob a bandeira de luta por liberdade, igualdade e fraternidade.

O movimento revolucionário francês é considerado heroico por sua luta contra os abusos cometidos pelo Estado Absolutista, pois seus progressos permitiram uma mudança drástica no rumo do Estado, e também do Direito.

Todavia, a tomada do poder pela burguesia, apesar de inegavelmente ter sido determinante para o florescimento de uma série de direitos e liberdades individuais do cidadão, não pode ser compreendida como uma vitória de toda coletividade.

O Estado Liberal, instaurado na Idade Moderna, foi uma reação ao Estado Absolutista que, abusando arbitrariamente de seu poder sobre os governados, gerou imensa insegurança jurídica nas relações econômicas, não garantindo aos governados a propriedade privada e a execução regular dos contratos.

Desta feita, o movimento liberal, que passou a deter tanto o poder econômico como político, implementou um modelo de Estado que prezava pela liberdade e igualdade, garantindo-a de forma negativa, se abstendo de intervir na Econômica, contrariamente ao modelo estatal do Antigo Regime.

Procurava-se estabelecer a segurança jurídica da qual se necessitava para progredir economicamente. Buscava-se desenvolvimento social e econômico por meio da não 
intervenção, não só na Economia, mas no sistema como um todo. Nesse período surgiram os chamados direitos fundamentais de primeira geração, que consistem em diversas liberdades oponíveis à interferência estatal, além da econômica, a de expressão, política, religiosa, etc.

Entretanto, o modelo econômico liberal não foi capaz de se autorregular, entrando em colapso, além de ter gerado profundas desigualdades sociais, contraditoriamente, inviabilizando a liberdade e igualdade dos hipossuficientes.

De modo que, com o colapso do modelo liberal, o Estado se reformulou, mudando de paradigma mais um vez, agora decidindo atuar ativamente nas relações econômicas para atingir o Bem Estar Social por intermédio da igualdade, agora compreendida materialmente.

Pudemos perceber, pela primeira vez com apoio da história, que o papel do Estado oscila de maneira pendular, ora com maior intervenção, ora com retração estatal. E que a primeira oscilação desse pêndulo levou duzentos anos para se concluir, chegando ao ápice da intervenção estatal. A segunda oscilação levou vinte anos para tomar o rumo de volta a um cenário mais liberal da economia. ${ }^{1}$

As sucessivas reestruturações da política do Estado frente à Economia, demonstram a busca incessante por equilíbrio social e econômico.

Afinal, a Economia é o meio pelo qual o homem tem acesso aos bens materiais indispensáveis à sua existência, trata-se de uma atividade essencial à sobrevivência. Com efeito, uma das medidas mais coercitivas que podem ser impostas no âmbito internacional é aquela que impõe restrições de comercialização aos Estados, a fím de obstar a atividade econômica internacional, pois geram prejuízos imensuráveis aos cidadãos e ao Estado. Os embargos econômicos são considerados pela $\mathrm{ONU}^{2}$ como forma de genocídio e do sua gravidade fora entendida como ato de guerra na Conferência Naval de Londres já em 1909.

A finalidade estatal não pode ser outra, senão a garantia e proteção da existência (digna) de seus governados, portanto, a defesa e manutenção de uma Economia

\footnotetext{
${ }^{1}$ AGUILLAR, 2009, Nota do Autor

${ }^{2}$ CONVENÇÃO PARA A PREVENÇÃO E REPRESSÃO DO CRIME DE GENOCÍDIO
}

Art. $2^{\circ} \mathrm{Na}$ presente Convenção, entende-se por genocídio os atos abaixo indicados, cometidos com a intenção de destruir, no todo ou em parte, um grupo nacional, étnico, racial ou religioso, tais como: (...)

c) Submissão deliberada do grupo a condições de existência que acarretarão a sua destruição física, total ou parcial 
próspera e estável, que preze pela igualdade material para que se atinja a justiça social, é meio idôneo para que o Estado atinja essa e outras finalidades.

Em razão da importância que a atividade econômica tem para assegurar a vida humana, elegi o tema da Intervenção Estatal na Economia como tema deste trabalho, pois é o meio disponível que o Estado tem de interferir no âmbito econômico, impondo suas políticas econômicas, a fim de conduzir o mercado segundo os princípios constitucionais e, por conseguinte, garantir aos seus administrados que da Economia usufruíam, prestando-se ao seu fim de proteger a existência digna do homem.

Desta maneira, inicialmente, no primeiro capitulo, o trabalho irá tratar da relação entre Direito, Economia e Estado. A importância dos três conceitos se interrelaciona como meios necessários à existência humana (digna) em sociedade, de forma regrada.

Em seguida, a despeito dos debates próprios da área econômica sobre a defesa dessa ou daquela política econômica, limitar-me-ei em expor os posicionamentos de políticas econômicas que historicamente conhecemos e que caracterizaram o Estado Liberal, Intervencionista e o Regulador, sem advogar por uma ou outra no âmbito econômico, apenas ponderando sua adequação em atingir os fins sociais do Estado.

No ponto seguinte, irei verificar o panorama constitucional geral que estrutura a Ordem Econômica da Constituição de 1988, explicando três de seus princípios capitais: o da Livre Iniciativa, Livre Concorrência e Função Social da Propriedade.

Por fim, após ter exposto os fundamentos principiológicos que condicionam a Ordem Econômica, passarei a descrever como a nossa Carta Magna entende a questão da intervenção estatal na Economia.

Para melhor demonstrar o entendimento de todo o paradigma constitucional em relação ao tema, irei analisar, sob a ótica da intervenção estatal e dos princípios constitucionais, a atividade do Banco Nacional de Desenvolvimento Econômico e Social - BNDES, empresa pública federal de grande relevância na atualidade que persegue o desenvolvimento econômico e social nacional, como explicita seu nome. 


\section{Conceitos Fundamentais}

Antes de adentrarmos no bojo do trabalho, faz-se mister, nesse primeiro capítulo, a delimitação de alguns conceitos basilares e essenciais para o desenvolvimento das ideias que nortearão a pesquisa.

Primeiramente, o tema tratado, a intervenção do Estado na Economia, requer explicação literal a fim de que seja esclarecido o conteúdo da pesquisa, bem como relação de essencialidade que a Economia tem para o homem e sua interação com a figura estatal e com o Direito. Em seguida, ao longo dos capítulos, a substância do tema será aprofundada em toda sua amplitude, ficando mais clara.

PLACIDO E SILVA explica que a palavra intervenção vem do latim interventio, de intervenire. Significa assistir, intrometer-se, ingerir-se. É associada à intromissão ou ingerência de uma pessoa em negócio ou assunto de outrem, em sentido amplo, podendo ser como mediador, intercessor, conciliador, fiscal, etc. Interventor ou interveniente é a pessoa que promove a intervenção, sendo seu agente principal. ${ }^{3}$

A partir desse conceito, verifica-se a existência de diversos tipos de intervenção na seara jurídica, dentre eles o da intervenção de terceiros no âmbito processual civil, o princípio da não-intervenção no direito internacional público, o princípio da intervenção mínima no direito penal, etc.

A presente pesquisa tratará de um aspecto específico de intervenção, a que ocorre na seara econômica, mais especificamente, da intervenção estatal na economia.

O tema é o ponto central da disciplina do Direito Econômico, e motivo que levou à criação desse ramo jurídico. De fato, a intervenção do Estado na Economia é o tema principal do Direito Econômico, sendo sua razão de ser.

\footnotetext{
${ }^{3}$ PLACIDO E SILVA,1996, p.506-507.
} 
Conforme se explicará, essa disciplina jurídica compreende a relação das políticas públicas com os agentes privados que controlam as forças produtivas econômicas.

\subsection{Economia}

O objeto do trabalho gira em torno da liberdade, frente à intromissão estatal, de atuação dos agentes privados na esfera da Economia, vocábulo que decorre do latim oeconomia, do grego oikonomia. Esta deriva da justaposição das palavras gregas oikos (casa, ambiente familiar, lar) e nomos (lei ou costume), traduzindo-se em normas do lar, o que nos remete à origem privada da atividade econômica. ${ }^{4}$

Economia refere-se tanto aos atos práticos, como à ciência que estuda a boa ordem no governo e administração de um negócio ou estabelecimento.

A despeito de sua polissemia, nos interessa a acepção de Economia como sinônimo da produção, circulação e consumo de riquezas, ou seja, bens e serviços necessários ou úteis à subsistência e conservação humana.

A obtenção de bens assume caráter urgente ao homem, pois é conditio sine qua non para a manutenção da sua existência.

Tendo em vista a impossibilidade em se obter toda a gama de bens que se careça, é a circulação de riquezas, a atividade econômica, a resposta às necessidades humanas. A Economia, consistindo basicamente na circulação de bens e riquezas, permitirá a alocação de recursos como solução à finitude, ou escassez, de bens, que se apresenta em face dos desejos humanos.

Tamanha a importância da Economia para organização social, que Marx, por intermédio do materialismo histórico, explica a configuração do Direito como uma superestrutura, de caráter ideológico, determinada pela infraestrutura econômica.

\footnotetext{
${ }^{4}$ PLACIDO E SILVA,1996, p.132.
} 
Para o célebre teórico socialista, a Economia condicionaria a produção cultural do homem, como as artes, a moral e o Direito. As forças econômicas modelariam a roupagem jurídica, inclusive a organização do Estado. ${ }^{5}$

Todavia, Miguel Reale ${ }^{6}$ afirma que a explicação marxista não explica de modo convincente a preexistência de uma estrutura econômica e independente ao Direito, já que este está sempre presente no meio social.

Por outro lado, quando uma nova técnica de produção determina a substituição de uma estrutura jurídica por outra, a nova estrutura repercute, por sua vez, sobre a vida econômica, condicionando-a. Há, pois, entre Economia e Direito uma interação constante, não se podendo afirmar que a primeira cause o segundo, ou que o Direito seja mera "roupagem ideológica" de uma dada forma de produção. Há, em suma, uma interação dialética entre o econômico e o jurídico (... $)^{7}$

Direito e Economia apresentam uma relação intricada, que não se reduz em um mero condicionamento daquele a esta, como veremos a seguir.

\subsection{Direito}

Convém retomar o conceito de Direito, afinal, a questão da intervenção estatal na Economia se dá no campo jurídico, pelo Direito Econômico, e parece interessante que se tome o fundamento do conceito, pois este determinará uma série de desdobramentos.

\footnotetext{
${ }^{5}$ REALE, 2002, p. 21.

${ }^{6}$ Idem.

${ }^{7}$ Idem.
} 
O Direito é comumente compreendido como lei e ordem, ou conjunto de regras obrigatórias destinadas a manter a coesão social ao coibir comportamentos individuais nocivos à estrutura social ${ }^{8}$. É condição essencial para a manutenção e subsistência da convivência social.

Do mesmo modo que o Direito é essencial para a sociedade, a experiência jurídica se origina das relações intersubjetivas, entre os homens. Desta feita, entende-se o Direito como um fato ou fenômeno social, não existindo fora da sociedade, e esta não podendo existir sem aquele: "ubi societas, ibi jus", onde reside a sociedade há necessariamente de existir o Direito para resguardá-la.

Embora, a priori, este raciocínio pareça ingênuo e despretensioso, a origem social do Direito é resultado de todo um paradigma que elege o homem e sua dignidade como núcleo de proteção ao qual o Direito se destinará.

A sociedade humana, diferentemente dos agrupamentos dos demais animais, não é uma construção natural. Ela se constitui de modos distintos a depender do lugar em que se estabelece e ao longo das épocas.

É resultado de processos históricos e culturais, ou seja, é um fato cultural, sua estruturação não é determinada por impulso de lei natural ou física, é construção humana e ao bem estar do homem se destina.

A convivência no seio da coletividade é indispensável à sobrevivência humana, nós somos seres sociáveis. A sociabilidade é uma condição adaptativa do homem, que o fez superar as adversidades naturais, e primordialmente, possibilitou a interação econômica para obtenção de bens urgentes à sua sobrevivência.

Por conseguinte, é decorrência lógica que o Direito, por ser uma ciência social, também é um a ciência cultural. ${ }^{9}$

O Direito cria leis vinculantes, utilizando-se, mas não se vinculando, dos juízos de valor dos demais campos do saber cultural (como a Economia) para formar suas convicções e

\footnotetext{
${ }^{8}$ REALE, 2002, p. 1-2.

${ }^{9}$ REALE, 2002, p. 31.
} 
construir normas ou regras que irão determinar qual deve ser o comportamento coletivo esperado $^{10}$, o que nos remete à relação dialética entre direito e economia.

REALE define o Direito, na acepção de ordenamento jurídico, ou seja, conjunto de normas ou regras jurídicas destinadas a traçar o comportamento humano, como uma "ordenação bilateral atributiva das relações sociais, na medida do bem comum". 11

Leonardo Vizeu Figueiredo delimita o conceito de forma semelhante, como "conjunto de normas coercitivamente impostas pelo Estado, com o fim de promover a pacificação e a harmonização da sociedade". ${ }^{12}$

Como mencionado, interessa-nos, o ramo jurídico do Direito Econômico, responsável por normatizar a atividade econômica de determinada sociedade, a fim de estudar, disciplinar e harmonizar as relações jurídicas entre os entes públicos e os agentes privados, detentores dos fatores de produção, nos limites legais para a intervenção estatal na ordem econômica ${ }^{13}$.

Ou seja, "é direito das políticas públicas na economia" ${ }^{14}$, o conjunto normativo destinado à concretização da política econômica adotada pelo Estado, para disciplinar em qual medida a influência estatal atuará sobre os agentes econômicos. Destina-se a instrumentalizar, por meio do ordenamento jurídico, a política econômica do Estado.

Ao fazermos um apanhado histórico, verifica-se que até o século XIX normas específicas de Direito Econômico eram insipientes, contudo já se verificava a necessidade de regulação em face do interesse coletivo como no precedente jurisprudencial americano Munn v. Illinois, de 1877, que considerou constitucional legislação que fixava preços de serviço de transporte grãos; e nas primeiras legislações antitruste, como o Act for the Prevention and Suppression of Combinations Formed in Restraint of Trade, de 1889, no Canadá, e o famoso

\footnotetext{
${ }^{10}$ REALE, 2002, p. 29.

${ }^{11}$ REALE, 2002, p. 59.

${ }^{12}$ FIGUEIREDO, 2011, p.4.

${ }^{13}$ FIGUEIREDO, 2011, p.7.

${ }^{14}$ AGUILLAR, 2009, p.1.
} 
Sherman Act, de 1890, legislação americana antitruste destinada a combater o abuso do poder econômico em face do consumidor. ${ }^{15}$ A disciplina assumiu concretude, se distinguindo de modo mais visível do Direito Privado, com a configuração política do Estado do Bem Estar Social.

A recenticidade é uma das características gerais do Direito Econômico, um ramo científico novo e dinâmico, sujeito às alterações do mercado econômico ${ }^{16}$. Sua constituição foi fortemente influenciada pelas ideias keynesianas de atuação do Estado na Economia, de modo que se advoga que decorra da própria atuação intervencionista estatal.

Inicialmente, no Estado Liberal, o Estado não se propunha a interferir na economia, deixando a cargo do Direito Privado e das forças econômicas a auto-regulação das relações econômicas.

Mesmo com a fraca ingerência estatal em sua fase liberal, o Estado não se dissociou das práticas econômicas capitalistas, afinal, foi por meio dele que se estabeleceram institutos jurídicos indispensáveis à economia de mercado, como a propriedade e os contratos.

Com a crise do liberalismo, o Estado viu-se obrigado a intervir na economia, tendo que regulá-la. Em razão da atuação do Estado no âmbito econômico fez-se necessária a normatização de sua conduta por intermédio do Direito Econômico.

\subsection{Direito Econômico e Estado}

O estudo do Direito Econômico, como mencionado, trata da política econômica estatal, portanto, não é possível tratar de Direito e Economia sem abordar os aspectos políticos que refletiram na estruturação e legitimação do Estado, e por consequência, na regulação econômica.

\footnotetext{
${ }^{15}$ AGUILLAR, p.255, 2009.

${ }^{16}$ FIGUEIREDO, 2011, p.11.
} 
Afinal, outra característica do Direito Econômico, defendida por alguns autores, é sua influência aos valores políticos ${ }^{17}$, o que importa na sujeição da legislação econômica à corrente ideológico-partidária de quem detém o poder político, embora seja uma sujeição limitada pelo que dispõe a Constituição.

Todavia, a influência exercida pelas correntes ideológicas que estão no poder sobre a política econômica restringe-se aos limites do poder discricionário outorgado pela própria Carta Magna.

Consequentemente, qualquer que seja a ideologia política que prevaleça na órbita estatal, não se pode contrariar as regras de planejamento econômico ou de intervenção estatal que estão descritas taxativamente na Constituição Federal.

Essa profunda relação entre o Direito Econômico e a organização política torna imperiosa a conceituação e análise do Estado e das correntes ideológicas que influíram nas suas políticas econômicas ao longo da história.

A fim de que se esclareça a situação jurídica vigente, que não deixa de ser um produto histórico, fruto de um processo de transformação gradual, primeiramente analisar-se-á os fundamentos que ensejam a instituição estatal, para em seguida abordar os aspectos históricos da relação entre o Estado e a intervenção econômica, relação de tamanha importância que influiu na própria estruturação do Estado e do Direito.

\subsection{Estado}

Nos primórdios da organização humana em sociedade, cada indivíduo tomava para si a efetivação de seus direitos, cada um fazia justiça com as próprias mãos, era a chamada autotutela.

\footnotetext{
${ }^{17}$ FIGUEIREDO, 2011, p.12-13.
} 
Com a evolução social, criou-se a figura do Estado, uma figura imbuída do dever de garantir a ordem e paz social aos indivíduos por meio do direito, o instrumento necessário para atingir o bem comum. Cabendo apenas a ele zelar pela efetivação dos direitos através de meios coercitivos.

Do latim statu, do verbo stare, estar de pé, manter-se. O vocábulo apresenta o radical st, de origem indo-europeia, que significa permanência, duração. (...) No Direito Político, é a sociedade dotada de poder soberano e voltada para o bem comum. (grifo nosso) ${ }^{18}$

Inúmeras teorias divagam sobre as origens das primeiras sociedades políticas, do Estado, e do Direito.

A arqueologia, etnologia e antropologia, ao estudarem os vestígios das primeiras sociedades humanas teorizam que a carência de organização, bem como de compor conflitos internos e manter o grupo unido, levaram a indicação de uma autoridade, a escolha de um dos membros da tribo que fosse mais apto, inteligente, forte ou hábil para guiar a sobrevivência dos demais.

As determinações dessa autoridade primitiva teriam trago mais prosperidade, melhores caçadas, e paz interna, surgiria uma figura primitiva de autoridade política, um embrião da autoridade estatal ${ }^{19}$.

$\mathrm{Na}$ seara jurídica, a teoria contratualista ou jusnaturalista ${ }^{20}$ tem grande prestígio para explicar o fenômeno do Estado. Os filósofos contratualistas explicam que o homem nascia livre, na natureza, longe das leis (positivas) ou do Estado. Então por que existiria a sociedade, ou o Direito?

\footnotetext{
${ }^{18}$ ACQUAVIVA, 1993, p.548.

${ }^{19}$ ACQUAVIVA, 1993, p.549.

20. É curioso notar que os politólogos falam de "contratualismo" e os juristas de "jusnaturalismo" para aludir, essencialmente, ao mesmo movimento intelectual. Olham de pontos diferentes para o Jano. O caso insinua o quão próximas as duas ciências podem achegar-se. Norberto Bobbio (In: Teoria Geral da Política: A filosofia Política e as Lições do Clássicos. Rio de Janeiro: Elsevier, pp. 216 e ss.) ilustrou a hipótese ao evidenciar a notável similitude entre as teorias jurídicas vinculadas à idéia de norma fundamental e as teorias políticas do Estado de direito. (FASSÓ, 2002, p. 658)
} 
O Direito, decorrente do Estado, e a sociedade civil (aquela que vive sob a égide jurídica do Estado) existem pois os homens teriam se associado e acordado em se submeter às regras que limitavam sua própria liberdade e dos demais, esse acordo era o contrato social.

Os teóricos contratualistas adotavam como primeiro passo a noção de estado de natureza, que aludia ao status do homem pré-político. Partindo daí, os contratualistas fundamentaram a moderna tradição política ocidental, alçando-se à referência indispensável no debate em torno do Estado e da política.

Reale diz que o contratualismo não é uma doutrina, mas um movimento que abrange várias teorias, muitas vezes conflitantes ${ }^{21}$. Dentre os grandes filósofos jusnaturalistas que utilizaram-se das ideias contratualistas como forma de complementar suas teorias estão Hobbes, Locke, e Rousseau.

O homem - diria um contratualista - primeiro vivia por si no mundo, alheio a qualquer vinculação intersubjetiva artificial. Nesse estado de natureza, o homem estava desprendido de qualquer sujeição, desfrutava de direitos inatos ou naturais e arrogava-se, se fosse o caso, na função de juiz das leis naturais.

Por uma razão ou outra, a depender do teórico, o homem resolvia então organizar-se social e politicamente, formando, mediante o consenso expresso no contrato social, unidades sócio-políticas.

Verbi Gratia, temos a teoria de um dos maiores contratualistas, Thomas Hobbes, filósofo do século XVII que concebeu seu trabalho em momento histórico no qual o absolutismo atingia seu apogeu.

Hobbes explica que a escassez de bens vai fomentar insegurança e desconfiança entre a humanidade. A necessidade por bens da vida, escassos, coloca o homem em conflito. Denota-se dessa afirmação mais uma prova da profunda importância da economia, agora, para o nascimento do Estado.

Como medida de autopreservação, todos os homens teriam que estar

\footnotetext{
${ }^{21}$ REALE, 2002, p. 648.
} 
constantemente buscando dominar os demais. O homem, por ser de natureza vil, entraria em discórdia com seus semelhantes.

Enquanto não houvesse um poder comum para manter todos sob "um temor respeitoso", inevitavelmente, os homens estariam num estado de guerra. Daí a aplicação da frase "homo homini lupus" (o homem é o lobo do homem).

Nesse estágio, não haveria leis, pois inexistia concordância ou submissão a alguém para fazê-las ou impô-las, portanto, não haveria injustiça ou nenhuma noção de certo ou errado. Existiria um medo constante e perigo de morte violenta. "E a vida do homem é solitária, miserável, sórdida, brutal e curta." 22

Onde não há poder comum não há lei, e onde não há lei não há injustiça. $\mathrm{Na}$ guerra, a força e a fraude são as duas virtudes cardeais. A justiça e a injustiça não fazem parte das faculdades do corpo ou espírito. ${ }^{23}$

Para que a paz seja alcançada, todos os homens devem conjuntamente resignar ao seu direito natural pleno até o limite em que os outros homens resignem também o seu, para viver em paz e em sociedade.

Para garantir o pacto social, requer-se um poder suficientemente forte, capaz de exercer coação através de sanções, inspirando medo nos homens, e forçando-os a cumprir o contrato, cessando a anarquia através de leis civis, garantindo a paz e segurança de todos: o Leviatã.

A coletividade deve submeter sua vontade e decisões ao possuidor do poder, dando a ele o monopólio de "toda a sua força e poder a um homem, ou a uma assembleia de homens, que possa reduzir todas as suas vontades, por pluralidade de votos, a uma só vontade $^{24 \text { ", } . O ~ L e v i a t a ̃, ~ o ~ d e u s ~ m o r t a l, ~ l e g i t i m a d o ~ p e l o ~ c o n t r a t o ~ s o c i a l, ~ q u e ~ i r a ́ ~ v e l a r ~ p e l a ~ p a z ~ e ~}$ segurança do seu povo, dando fim a guerra generalizada do estado de natureza, é o Estado.

\footnotetext{
${ }^{22}$ HOBBES, 2008, p. 109.

${ }^{23}$ HOBBES, 2008, p. 111.

${ }^{24}$ HOBBES, 2008, p.147.
} 
Autorizo e transfiro o meu direito de me governar a mim mesmo a este homem, ou esta assembleia de homens, com a condição de transferires para ele o teu direito, autorizando de uma maneira semelhante todas as suas ações 25

Essa teoria contratualista revela o caráter central que a propriedade e os bens têm na configuração social, estando sua salvaguarda diretamente ligada à criação do Estado. Afigura-se razoável o raciocínio de que o papel do Estado, embora forte e centralizado, passa pelo bem comum, que está vinculado à garantia da segurança para o exercício da propriedade e das relações econômicas.

Embora Hobbes tenha sido associado como teórico monarquista, fortalecendo argumentos pró-absolutistas, sua teoria objetiva demonstrar a necessidade de um Estado totalitário, forte, e não necessariamente monárquico. Como explicado, existe também a possibilidade do poder estatal repousar nas mãos de uma assembleia.

Apesar de que esteja disseminada essa visão preconceituosa do trabalho de Hobbes, que o associa ao Absolutismo, as razões que levariam à criação de um Estado, a proteção da propriedade e o ordenamento social, também justificariam a queda do Estado que deixa de atender suas razões de ser.

Historicamente, a teoria hobbesiana, ao defender um Estado totalitário, foi utilizada, juntamente com a doutrina de Maquiavel, para legitimar as estruturas do Estado Absolutista, bem como as ações desmedidas e arbitrárias do monarca. Inúmeras vezes a conduta do soberano gerou consequências contrárias ao propósito fundamental do Estado, deixando de garantir a segurança ao exercício da propriedade e a realização da paz social.

Portanto, seria lógico que ao deixar de atender as razões que levaram à legitimação do Estado, os indivíduos pudessem rever a liberdade que depositaram no Estado e passassem a questioná-lo. Basicamente, foi essa situação que ensejou a revisão do Estado Absolutista. Uma vez mais, a propriedade foi o núcleo da questão, motivo ensejador dessa revisão.

A insegurança instaurada, consequência dos arbítrios do soberano no trato das

\footnotetext{
${ }^{25}$ Idem.
} 
relações econômicas realizadas pela burguesia, levaram ao fomento do liberalismo e a criação do Estado Liberal.

\subsection{Estado de Direito}

Com o fortalecimento das ideias liberais burguesas, a doutrina alemã ${ }^{\mathbf{2 6}}$, fortemente influenciada por elas, ao tratar do tema da teoria do Estado, construiu o conceito de Estado de Direito, que seria o Estado da Razão, no qual o governo deveria ser condicionado pela vontade geral consubstanciada na lei, guiado de forma racional, buscando-se o bem para todos os integrantes da coletividade.

O Estado de Direito foi criado como argumento teórico para restringir a atividade estatal por meio da lei, se contrapondo ao Estado Absolutista, o Estado-Poder, como aquele idealizado por Hobbes.

(...) é também uma criação da teoria do Estado do precoce liberalismo alemão, cujo âmbito significava Estado da razão; o Estado do entendimento; ou, mais detalhadamente, o Estado em que se governa segundo a vontade geral racional e somente se busca o que é melhor para todos. ${ }^{27}$

No Estado de Direito, a lei emanada pelo próprio Estado irá submeter também a sua atuação e não apenas os particulares, ambos passarão a estar adstritos a ela.

A finalidade inicial do Estado fundado na lei era garantir a liberdade e a segurança das pessoas e da propriedade, a fim de favorecer o desenvolvimento individual.

A ideia de Estado de Direito, inicialmente, vinculou-se ao direito administrativo, foi uma reação aos abusos desenfreados do Estado Absolutista perante seus governados. Consistiu em uma construção teórica da classe social burguesa, contraria ao Absolutismo, a fim de servir seus interesses econômicos e legitimar a ideologia liberal.

\footnotetext{
${ }^{26}$ MENDES, 2008, p. 42

${ }^{27}$ Idem.
} 
O fato é que as teorizações do Estado de direito nascem da luta burguesia contra o poder absoluto do monarca, isto é, da luta pelo Estado juridicamente controlado/limitado, cuja legitimidade não carece mais de fundamento teológico, transcendente, metafísico. ${ }^{28}$

Ao fim do Absolutismo, foi instituído um modelo de Estado, de direito e, por conseguinte, de Constituição, reflexos dos princípios liberais-individuais que favoreciam especialmente a classe social detentora do poder econômico, que agora detinha também o poder político $^{29}$.

O Estado de Direito foi um arcabouço jurídico, criado para legitimar e dar roupagem ao Estado Liberal e seus interesses.

$\mathrm{O}$ modo de produção capitalista, que elege como ratio fundamentalis do ordenamento político o lucro, coloca o direito positivo a seu serviço; é isso que explica a estruturação do direito posto pelo Estado moderno. Ele existe fundamentalmente - desejo deixar este ponto bem vincado - para permitir a fluência da circulação mercantil, para tentar "domesticar" os determinismos econômicos. (...) o capitalismo [leia-se: o Terceiro Estado, a burguesia] necessita da ordem, mas a detesta, procurando a qualquer custo exorcizá-la. Dizendo-o de outro modo: o mercado exige, para satisfação do seu interesse, o afastamento ou a redução de qualquer entrave social, político ou moral ao processo de acumulação de capital. Reclama atuação estatal para garantir a fluência de suas relações, porém, ao mesmo tempo, exige que essa atuação seja mínima. ${ }^{30}$

Futuramente, com o enfraquecimento do caráter liberal do Estado, o Estado de

Direito assumiu outras finalidades, e foi adotado pelo direito constitucional como forma de legitimar todo o sistema jurídico.

Atualmente o termo traduz a ideia de Estado pautado pelo império da lei, como expressão da vontade geral, com tripartição de poderes, e garantidor de direitos e liberdades fundamentais. Tendo em vista a influencia das políticas liberais na transformação do Estado, e sua estruturação jurídica, é deveras necessário que analisemos o perpassar histórico das política econômica até a atualidade, a fim de que possamos compreender as origens e motivos de nossa atual conjuntura.

\footnotetext{
${ }^{28}$ GRAU, 2010, p.37.

${ }^{29}$ GILMAR MENDES, 2008, p.46.

${ }^{30}$ GRAU, 2010, p.34-35.
} 


\section{Do Estado Liberal aos dias atuais}

O direito econômico trata essencialmente da ingerência do Estado nas relações econômicas, focando seus dispositivos, com prevalência, na autonomia da vontade autonomia das partes $^{31}$. Dentre suas características gerais, além da recenticidade e a influência aos valores políticos, estão a singularidade e o concretismo.

O direito econômico é um ramo jurídico com singularidade, pois trata do fato econômico peculiar à realidade local do país. Suas normas são específicas e setoriais, não são universais e cosmopolitas.

Afinal, a realidade do mercado, apesar de globalizado, reflete as peculiaridades do local, do mesmo modo o direito econômico deve se pautar, pois é sobre o mercado específico que ele irá influir ${ }^{32}$.

Portanto, há necessidade de se avaliar as condições específicas do mercado a ser regulado juridicamente.

A característica da singularidade se relaciona ao concretismo ${ }^{33}$ do direito econômico, pois este normatiza fenômenos socioeconômicos concretos, relacionados à fatos históricos de importância para o Estado e os indivíduos de determinada sociedade.

(...) não pode o Direito isolar-se do ambiente em que vigora, deixar de atender às outras manifestações da vida social e econômica. (...) As mudanças econômicas e sociais constituem o fundo e a razão de ser de toda a evolução jurídica; e o direito é feito para traduzir em disposições positivas e imperativas toda a evolução social $^{34}$

Essas qualidades do Direito Econômico, juntamente com a influência aos valores políticos, elegem grande importância ao Estado e ao histórico de suas políticas

\footnotetext{
${ }^{31}$ FIGUEIREDO, 2011, p.11.

${ }^{32}$ Idem.

${ }^{33}$ FIGUEIREDO, 2011, p.13-14.

${ }^{34}$ MAXIMILIANO, 1997, p.157-159.
} 
econômicas para que se compreenda apropriadamente o direito econômico. Afinal, essa disciplina jurídica tem como objeto a relação do Estado e sua política econômica em face da atividade econômica dos particulares.

Deste modo, é imperativo, para que se compreenda o direito econômico hodierno, que se analisem as transformações mais relevantes pelas quais o Estado e sua política econômica passaram, bem como os fatos históricos que repercutiram na órbita econômica, tanto dentro do Estado brasileiro, como os de impacto global.

Apesar das especificidades locais, é inegável a globalização da economia bem como das ideologias que legitimam as estruturas de poder político. Logo, a estrutura estatal e suas políticas econômicas, se organizaram de forma semelhante ao redor do globo, o que possibilitou certa categorização. A explicação dessas categorizações nos permitirão compreender em linhas gerais as políticas econômicas que os Estados adotaram ao longo do tempo, bem como entender as origens que levaram ao momento atual da legislação constitucional pátria.

\subsection{Estado Liberal}

O pensamento econômico hodierno nasceu no seio do Estado Liberal, após a derrocada do Estado Absolutista. O Estado Absolutista, monárquico, caracterizava-se pela centralização dos poderes estatais na figura do rei, inibindo direitos individuais oponíveis às determinações estatais.

Com a necessidade dos súditos em conter os abusos do soberano, lutou-se por direitos e garantias individuais. Teve-se como marco inicial a Magna Carta (Constituição do Rei João Sem-Terra), e essa luta por direitos eclodiu na Revolução Francesa, e a edição da Declaração Universal dos Direitos do Homem e do Cidadão.

(...) a burguesia, apropriou-se do Estado e é a seu serviço que este põe o direito, instrumentando a dominação da sociedade civil pelo mercado. O Estado, que inicialmente regulava a vida econômica da nação para atender as necessidades ditadas pela suas finanças, desenvolvendo políticas mercantilistas, passou a fazê- 
lo para assegurar o laissez faire e, concomitantemente, prover a proteção social, visando à defesa e preservação do sistema. Na sexta década do Século XIX, o capitalismo constitui as forças produtivas adequadas ao seu conceito e, daí, engendra sua dinâmica específica, a busca incessante da acumulação da riqueza abstrata. $^{35}$

Com a queda da monarquia, o Estado Absolutista foi sucedido pelo Estado Liberal, Estado Burguês ou Estado moderno, tendo como subsídio jurídico o ante mencionado Estado de Direito.

O Estado Liberal baseava-se nas doutrinas filosóficas e políticas do liberalismo, resumidamente, defendia-se que o Estado deveria primar pela liberdade individual, o respeito do exercício pleno dos direitos e garantias individuais, agora, eleitos como fundamentais.

Interessa ao presente estudo o traço característico desse modelo de Estado, a liberdade de mercado. indicada pela expressão fisiocrata "laissez-faire, laissez-passer; le monde va de lui-même".

Essa característica, embora comumente associada ao liberalismo foi inicialmente defendida por Quesnay, teórico da escola econômica fisiocrata, corrente econômica anterior à escola cássica, e por seus discípulos Turgot e Gournay que vieram a influenciar as ideias de Adam Smith e a escola clássica.

Smith acreditava que a Economia se autorregulava por meio de sua "mão invisível", descrevia que o sistema econômico se auto-organizava, sendo praticamente desnecessária a intromissão regulatória do Estado, cabendo a este apenas assegurar a manutenção interna da ordem social.

A doutrina liberal refletiu em um legislação absentista, neutra e imparcial quanto à intervenção econômica estatal, e fundava-se no princípio da livre iniciativa do cidadão, autorizando o exercício livre da atividade econômica, sem restrições.

Outro de seus fundamentos era a liberdade de contratar, cabendo ao Estado apenas garantir a execução contratual, dando segurança jurídica aos jurisdicionados.

\footnotetext{
${ }^{35}$ GRAU, 2010, p.29-30.
} 
O Estado Liberal caracterizava-se pelo princípio da autonomia da vontade das partes, e absolutismo dos direitos privados: propriedade e liberdade.

No entanto, ao final do século XIX, já se noticiava no Canadá e nos Estados Unidos a edição de leis antitruste, com o objetivo de coibir práticas contrárias ao exercício da livre concorrência. ${ }^{36}$ Demonstrava-se uma tendência inicial, contrária ao abstencionismo estatal na econômica, que viria a se confirmar.

\subsection{A crise do liberalismo - Estado Intervencionista}

Nas primeiras décadas do século XX, o Estado Liberal já demonstrava sinais patentes de sua inadequação, entrando fatalmente em crise. Os direitos individuais, exercidos de forma desenfreada nesse período, levaram à concentração dos fatores de produção nas mãos de poucos particulares, levando à desigualdade de renda e abusos contra a livre concorrência necessária à adequada conservação do mercado.

Outros efeitos negativos, talvez mais impactantes, desse tipo de política econômica abstencionista foram o surgimento de abismos sociais no âmbito interno dos países, e o acirramento das desigualdades internacionais, que culminaram com a Primeira Grande Guerra, e conseguintemente com a Segunda Guerra Mundial.

A crise desse modelo de Estado gerou conflitos econômicos e políticos, opondo de um lado a burguesia, detentora dos meios de produção e do poder econômico, ao proletariado, força motriz desse modelo de mercado. Foi esse embate que fez surgir as teorias de cunho socialista e comunista, que vieram a serem implementadas no Estado Socialista no qual se buscava a igualdade material e desenvolvimento social de forma tão acirrada que chegou-se a abolir a propriedade privada praticamente em sua totalidade.

\footnotetext{
${ }^{36}$ AGUILLAR, 2009, p.254.
} 
Em face ao caos social decorrente dessas desigualdades, surgiram os direitos fundamentais de segunda geração, uma resposta às necessidades da grande massa trabalhadora explorada em demasia pela burguesia liberal. Estes eram direitos de natureza social, que demandavam prestações positivas do Estado, como direito à saúde, à previdência social, direito trabalhista, etc.

Como resposta aos abusos perpetrados por aqueles que detinham o domínio dos fatores de produção, e que sistematicamente contrariavam a saúde do mercado ao desrespeitar a livre concorrência, os Estados passaram a valer-se de legislações antitruste.

Outro evento de fundamental importância para o declínio do liberalismo foi a Crise Econômica Mundial de 1929, responsável pelo desemprego de milhares de pessoas, em razão do fechamento de empresas e bancos.

Os Estados Unidos, amparados pela Doutrina Monroe, de cunho extremamente liberal e isolacionista, tinha a economia mais dinâmica e poderosa do mundo após a Primeira Guerra Mundial. Todavia, foi na bolsa americana que eclodiu a crise, ocasionada por uma superprodução de produtos.

A concentração de renda nas mãos de poucos e o reduzido poder aquisitivo da maior parte da população, o proletariado, inviabilizou a expansão do consumo interno.

A ausência de consumo interno conjugada com o isolacionismo americano implicou na estocagem de produtos, esta, combinada com a intensa especulação financeira, levou à quebra da bolsa americana em 1929, a qual repercutiu em praticamente todo o mundo.

Esse episódio expôs a necessidade de regulação da economia, enfraquecendo a teoria liberal de Adam Smith, e dando espaço ao discurso intervencionista do inglês John Maynard Keynes.

Ainda nos Estados Unidos, no início da década de 30, as eleições mudaram o rumo da política econômica americana, criou-se um plano econômico chamado New Deal, baseado nas idéias keynesianas de intervenção na economia, que foram aplicadas na tentativa de limitar o liberalismo econômico. 
Assim, sepultou-se de vez a ideologia defendida por Adam Smith. O New Deal praticamente conseguiu recuperar, no espaço de uma década, a economia americana, por meio de um planejamento econômico vinculado à intervenção estatal.

O presidente à época, Franklin Roosevelt determinou aumento na emissão de moeda, com a intenção de inflacionar o sistema financeiro, investiu na criação de hidrelétricas, estimulou políticas de emprego, entre outras que permitiram o crescimento do consumo.

Esse novo modelo de política econômica, intervencionista, caracterizou o Estado Intervencionista.

\subsubsection{Estado Intervencionista Econômico}

A doutrina distingue o Estado Intervencionista em duas espécies, o Estado Intervencionista Social e o Estado Intervencionista Socialista. Interessa-nos, em razão do modo de produção capitalista ter historicamente prevalecido sobre o socialismo, o estudo do primeiro tipo.

Todavia, parte da doutrina, defende um tertium genus, o Estado Intervencionista Econômico. ${ }^{37}$ Que compreenderia aquele em que foi adotada a política econômica do New Deal e antecederia o Estado Intervencionista Social.

Ele objetivava garantir as liberdades individuais de forma racional, inadmitindo abusos que eram recorrentes no liberalismo. Diferencia-se do Estado Intervencionista Social, pois ainda não havia uma preocupação maior com o aspecto social decorrente da atividade econômica, seu foco era defender o princípio da defesa da concorrência.

${ }^{37}$ FIGUEIREDO, 2011, p.39-40. 
O poder público tinha o objetivo primário de garantir a livre concorrência, fortalecendo sua legislação antitruste de modo a garantir igualdade na competição econômica e favorecendo a livre iniciativa de quem quisesse ingressar em atividade produtiva.

As políticas públicas destinavam-se ao crescimento econômico, e ao aumento da força produtiva pela geração de empregos com remuneração suficiente à subsistência e que permitisse o consumo, como forma de acelerar o crescimento econômico.

\subsubsection{Estado Intervencionista Social - Estado do Bem Estar Social}

O Estado Intervencionista Social, mais conhecido como Estado do Bem Estar Social, Welfare State, ou ainda Estado da Providência, é aquele que tem como razão de ser, a efetivação de políticas públicas assistencialistas, de promoção social.

O Welfare State, além de normatizar a Ordem Econômica para garantir o exercício racionalizado das liberdades individuais, criou direitos fundamentais visando proporcionar o bem estar dos indivíduos.

Além das preocupações presentes no Estado Intervencionista Econômico, essa forma estatal de intervenção protegia os interesses transindividuais da coletividade e mitigava os interesses individuais. Quer dizer, o Estado interfere de modo a reduzir o impacto naturalmente excludente da economia capitalista sobre as classes mais pobres.

No seu novo papel, o Estado, ao atuar como agente de implementação de políticas públicas, enriquece suas funções de integração, de modernização e de legitimação capitalista. ${ }^{38}$

\footnotetext{
${ }^{38}$ GRAU, 2010, p.43.
} 
Foi preconizado pela Constituição mexicana de 1917 e na Carta de Weimar de 1919. Fundamenta-se no princípio da solidariedade, que preceitua a repartição dentre todos os membros da coletividade os riscos sociais.

O Estado incube-se de efetivar os direitos fundamentais de caráter social, como emprego, previdência, educação, saúde, saneamento, etc., por meio de prestações positivas, abandonando o abstencionismo característico do Estado Liberal.

Ademais, o Estado, ainda, atua em áreas econômicas consideradas fundamentais para o desenvolvimento nacional, tornando-se verdadeiro agente econômico.

Esse modelo de intervenção estatal sofreu duras críticas justamente por sobrecarregar o Estado com gastos excessivos, já que o Estado assume responsabilidades aquém de sua capacidade, pois se torna prestador de serviços públicos e empreendedor de atividade econômica. $^{39}$

Um dos fatores determinantes que levou ao seu abandono foi o intenso empreendedorismo estatal. O Estado deixou de preocupar-se em incentivar a produção dos particulares, uma vez que ele próprio passou a ser um dos agentes econômicos, entrando em concorrência direta com os demais.

Por conta disso, instalou-se um ambiente adverso ao investimento econômico privado e certa insegurança jurídica, resultando em restrição da livre iniciativa. ${ }^{40}$

\subsection{Estado Regulador ${ }^{41}$}

O modelo do Bem Estar Social manteve-se predominante até o fim dos anos $70^{42}$, todavia, quando já se criava uma nova política intervencionista, mais adequada aos moldes

\footnotetext{
${ }^{39}$ FIGUEIREDO, 2011, p.41.

${ }^{40}$ Idem.

${ }^{41}$ FIGUEIREDO, 2011, p. 42-43.
} 
do capitalismo da época (levando se em conta as demandas sociais), que culminou com o Estado Regulador.

No âmbito jurídico, esse momento coincide com uma reformulação do conceito de Estado de Direito contemporâneo do Estado Liberal, o Estado passa ser denominado Estado Democrático de Direito.

O Estado Regulador teve como teóricos Friedrich von Hayek e a escola monetarista de Chicago, que pregavam a doutrina do neoliberalismo, inspirada nos ensinamentos da escola econômica neoclássica.

Tendo como influência os teóricos neoliberais, mas não resumindo sua atuação a essa doutrina, o Estado Regulador foi uma forma de repensar a atuação do Estado diante da economia capitalista e a carência de políticas de inclusão social. Abandonou-se as exorbitantes responsabilidades sociais do Estado que tanto sobrecarregaram as contas públicas e retomou-se o destaque da livre concorrência.

Embora não tivesse havido um retorno ao liberalismo pleno de outrora, os princípios liberais tomaram novo fôlego. Ainda assim, permaneceu a preocupação com as questões sociais e a garantia de bens essenciais á dignidade da pessoa.

O Estado retomou seu papel de garantidor dos princípios da livre iniciativa e livre concorrência, agora, de forma positiva, normatizando e combatendo condutas adversas a esses fundamentos.

Pautado pelo interesse coletivo, ele realiza intervenções pontuais para estimular a livre concorrência, inclusive reduzindo ganho de particulares, restringindo o poder econômico para evitar abusos que inviabilizem a participação e permanência de outros agentes econômicos no mercado. Garante-se, assim, o bem estar da Ordem Econômica. Consequentemente, adotou-se uma política desestatizante para promover a livre concorrência.

Quanto às políticas públicas de natureza social, foram reduzidas para preservar o equilíbrio financeiro estatal, contudo, não se abandonou os serviços públicos essenciais à

\footnotetext{
${ }^{42}$ DORIGO, 2001, p.503.
} 
existência digna dos cidadãos. Surge aí uma concorrência entre os direitos típicos do Estado do Bem Estar Social e do Estado Liberal.

Essa forma de intervenção fundamenta-se no princípio da subsidiariedade, o Estado interferiria somente quando a iniciativa privada não realizasse sua atividade no interesse da coletividade.

A exploração econômica retornou ao setor privado, que deve exercê-la dentro do planejamento estatal que vislumbra a efetivação de metas sociais, rumo ao desenvolvimento, não apenas econômico, mas também social.

As constituições nacionais passaram a adotar o dirigismo da economia, determinando ao Estado a função de normatizar as prestações materiais no âmbito econômico, de modo que sejam prestadas de forma a realizar os objetivos constitucionais.

Esse dirigismo implica maior destaque do direito público, pois tanto a Constituição quanto a legislação ordinária fixarão diretrizes gerais, contudo, os atos executivos é que irão adquirir maior volume e normatizar de fato as relações econômicas, com o fim de adequar a atividade econômica aos fins sociais.

Assim, após a caracterização dos diversos tipos globais de configuração de Estado frente à intervenção na economia, com adoção de políticas econômicas próprias, passaremos a analisar a situação nacional no capítulo seguinte. 


\section{A Constituição de 1988}

\subsection{Histórico Nacional}

A economia nacional, ou ordem econômica na acepção de mundo do $\operatorname{ser}^{43}$ (dos fatos em sua natureza pura), desenvolveu-se, inicialmente, nos tempos de Colônia, em torno de uma economia extrativista e escravista voltada para o abastecimento do mercado externo, a Metrópole, Portugal.

Posteriormente, no período do Império, apesar de ainda basearmos nossa produção no trabalho escravo, já se falava em produção interna, de caráter agrário, ainda voltada para o consumo externo. A centelha de industrialização liderada na época pelo Visconde de Mauá não se desenvolveu, então, mantivemo-nos numa economia agropecuária até o início do período republicano.

A produção econômica nacional veio a efetivamente iniciar sua industrialização no governo de Getúlio Vargas, no Estado Novo, com o incentivo das indústrias de base, que ficavam sob o controle estatal, pois a iniciativa privada permanecia em atividades rurais. Um dos ícones desse período foi a criação da Companhia Siderúrgica Nacional (1941) e da Vale do Rio Doce (1943).

A ordem jurídica econômica do país, no sentido do mundo do dever ser ${ }^{44}$ (aquele que sofre alteração na sua conformação por imposição da norma), nasceu durante o governo de Vargas.

Nesse período, havia alta estatização da economia, por meio da criação de empresas estatais em setores originalmente privados (empreendedorismo estatal) e prestação de serviços públicos essenciais ao cidadão.

\footnotetext{
${ }^{43}$ GRAU, 2010, p. 68.

${ }^{44}$ Idem.
} 
A insipiente normatização econômica nacional demonstrava atributos próprios do modelo de Estado Intervencionista Social, demonstrando estar em consonância com o modelo que estava em ascensão no restante do mundo após o advento das primeiras constituições econômicas.

As constituições econômicas, em geral, nasceram a partir da Primeira Guerra Mundial, independente da vertente política que adotassem, tanto no Estado do Bem Estar Social, como no Estado Socialista, seguiu-se uma linha de pensamento que refutava a ideia de liberalismo e de auto-regulação econômica.

A constituição de Weimar ${ }^{45}$, de 1919, uma das precursoras da defesa e garantia de direitos sociais e intervencionismo estatal ${ }^{46}$, foi a primeira a conter em seu texto uma seção especial normatizando a economia: "A vida econômica" 47.

Inspirada nela e na Carta del Lavoro de 1927 (declaração de princípios constitucionais pelo regime fascista), a Constituição Brasileira de 1934 foi a primeira a destinar um capítulo para Ordem Econômica e Social - "Da Ordem Econômica e Social" - que compreendia os artigos 115 à 143. O preâmbulo já anunciava que seria assegurada "à Nação a unidade, a liberdade, a justiça e o bem-estar social e econômico" ${ }^{48}$.

A carta magna de 1934 continha dispositivos de caráter intervencionista, que limitavam a liberdade econômica sob a ótica dos princípios da justiça social, a fim de proteger os interesses nacionais e garantir existência digna a todos.

Art. 115 - A ordem econômica deve ser organizada conforme os princípios da Justiça e as necessidades da vida nacional, de modo que possibilite a todos existência digna. Dentro desses limites, é garantida a liberdade econômica. ${ }^{49}$

\footnotetext{
${ }^{45}$ MOREIRA, 1974, p.70.

${ }^{46}$ FIGUEIREDO, 2011, p.41.

${ }^{47}$ Apesar de Weimar ser a primeira constituição com uma regulação econômica expressa, ou seja, uma Constituição Econômica formal, isso não importa na inexistência de prévias Constituições Econômicas materiais. Afinal, os direitos de propriedade, de liberdade contratual, de liberdade de comércio e indústria, embora fossem direitos individuais, não deixavam de serem garantias constitucionais oponíveis ao estado para permitir o livre exercício da economia capitalista liberal.

${ }^{48}$ Constituição de 1934

${ }^{49}$ Idem.
} 


\begin{abstract}
Nosso momento histórico fazia-se notar em dispositivos nacionalistas e intervencionistas, demonstrando o caráter antiliberal da constituição brasileira à época, inegavelmente evidenciando uma política econômica próxima do Estado do Bem Estar Social.
\end{abstract}

Previa-se, ainda, a intervenção na econômica com o intuito de fomentá-la, todavia, de forma a concentrar certas atividades nas mãos do Estado, através da "nacionalização" de empresas privadas.

Art. 117 - A lei promoverá o fomento da economia popular, o desenvolvimento do crédito e a nacionalização progressiva dos bancos de depósito. Igualmente providenciará sobre a nacionalização das empresas de seguros em todas as suas modalidades, devendo constituir-se em sociedades brasileiras as estrangeiras que atualmente operam no País.

A Constituição de 1937 adotou normatização semelhante, já em 1946, a nova Constituição fez alterações relevantes, embora mantivesse o aspecto intervencionista, inclusive com a previsão de monopólio estatal em seu artigo 146, procurou adequar o estímulo estatal à iniciativa privada, subordinando o exercício das liberdades individuais aos direitos fundamentais. ${ }^{50} \mathrm{O}$ artigo 147 inovou ao condicionar o exercício da propriedade ao bem-estar social.

Art. 146 - A União poderá, mediante lei especial, intervir no domínio econômico e monopolizar determinada indústria ou atividade. A intervenção terá por base o interesse público e por limite os direitos fundamentais assegurados nesta Constituição.

Art. 147 - O uso da propriedade será condicionado ao bem-estar social. A lei poderá, com observância do disposto no art. 141, § 16, promover a justa distribuição da propriedade, com igual oportunidade para todos.

Posteriormente, no governo de Juscelino Kubitschek, fez se um plano de metas, o Estado manteve investimentos em transportes, energia, alimentos, indústria de base, etc.

O tipo de política econômica do Estado, apesar de nuances específicas, perpetuou-se ainda durante o Regime Militar, o que ocasionou um grande endividamento externo,

\footnotetext{
${ }^{50}$ FIGUEIREDO, 2011, p.51.
} 
e dependência econômica externa. O Estado brasileiro à época, apesar de garantir a livre iniciativa, detinha grandes poderes para intervir.

Na Carta Magna de 1967, o Estado manteve-se se intervencionista, porém já sinalizava uma aproximação da ideologia neoliberal, além de consagrar a sujeição da Ordem Econômica à justiça social, o desenvolvimento nacional, além de prever a intervenção econômica para garantir a livre iniciativa e concorrência ${ }^{51}$.

Com a queda do Regime Militar, o país passou por um processo de redemocratização no qual foi estabelecido novo paradigma constitucional e econômico, a Constituição de 1988. Ela adotou uma tendência crescente de desestatização da Economia, aproximando-nos de um Estado Regulador, conforme o Art. 174 da nossa Carta Magna.

Art. 174. Como agente normativo e regulador da atividade econômica, o Estado exercerá, na forma da lei, as funções de fiscalização, incentivo e planejamento, sendo este determinante para o setor público e indicativo para o setor privado.

Iniciou-se no governo Collor a privatização de várias estatais, os setores explorados das estatais retomaram ao âmbito privado, tendência que teve seguimento nos governos seguintes.

Ficou claro ao Estado sua incapacidade em gerir uma atuação em duas frentes, como prestador de serviços essenciais e empreendedor responsável pelo desenvolvimento econômico do país.

Optou-se por abdicar da atuação econômica do Estado em favor de agentes privados, conforme demonstra o art. $1^{\circ}$ da Lei $n^{\circ}$ 9.491/97, que normatiza o Programa Nacional de Desestatização.

Art. $1^{\circ}$ O Programa Nacional de Desestatização - PND tem como objetivos fundamentais:

I - reordenar a posição estratégica do Estado na economia, transferindo à iniciativa privada atividades indevidamente exploradas pelo setor público;

\footnotetext{
${ }^{51}$ FIGUEIREDO, 2011, p.51.
} 
II - contribuir para a reestruturação econômica do setor público, especialmente através da melhoria do perfil e da redução da dívida pública líquida;

III - permitir a retomada de investimentos nas empresas e atividades que vierem a ser transferidas à iniciativa privada;

IV - contribuir para a reestruturação econômica do setor privado, especialmente para a modernização da infra-estrutura e do parque industrial do País, ampliando sua competitividade e reforçando a capacidade empresarial nos diversos setores da economia, inclusive através da concessão de crédito;

V - permitir que a Administração Pública concentre seus esforços nas atividades em que a presença do Estado seja fundamental para a consecução das prioridades nacionais;

A passagem das atividades, antes públicas, para o setor privado tornou imprescindível a atuação regulatória, fiscalizatória e de planejamento pelo Estado. O Poder Público deixou de interferir na Economia nos moldes do Estado Social, e passou a adotar os intervencionismos próprios do Estado Regulador.

\subsection{Ordem Econômica na Constituição de 1988}

EROS GRAU ${ }^{52}$ ensina que a ordem jurídica - sistema de princípios e regras jurídicas - compreende uma ordem jurídica pública e uma ordem jurídica privada; uma ordem econômica e uma ordem social. A ordem pública econômica é definida como "o conjunto das medidas, empreendidas pelo poder público, tendentes a organizar as relações econômicas" ${ }^{\text {"53. }}$.

(...) a descrevo, agora, como conjunto de normas que define, institucionalmente, um determinado modo de produção econômica. Assim, ordem econômica, parcela da ordem jurídica (mundo do dever-ser), não é senão o conjunto de normas que institucionaliza uma determinada ordem econômica (mundo do ser) ${ }^{54}$.

\footnotetext{
${ }^{52}$ GRAU, 2010, p. 58.

${ }^{53}$ GRAU, 2010, p.59.

${ }^{54}$ GRAU, 2010, p.70.
} 
Apesar do direito econômico não se limitar ao estudo da ordem econômica constitucional, pois sua normatização também ocorre por via da legislação ordinária e regulamentação do Poder Executivo, a Constituição é a base para o estudo da política econômica estatal. Afinal, a Constituição é norma fundamental, que vai dar unidade e validade às normas de hierarquia inferior, estruturando todo o sistema jurídico ${ }^{55}$.

O tratamento constitucional da atividade econômica é um fenômeno recente, que se relaciona diretamente à mencionada transição do Estado Liberal para o Estado Social.

Historicamente, as primeiras constituições, liberais, não dispunham de normatização expressa dedicada à atividade econômica. Afinal, elas consagravam direitos fundamentais de primeira geração que prestigiavam liberdades individuais, os quais pressupunham um dever de abstenção do Estado. Não obstante houvesse dispositivos que reflexamente repercutiam na esfera econômica.

Apesar dessa supressão intencional das constituições liberais, a doutrina discorda da inexistência de constituição econômica.

Denomina-se constituição econômica o conjunto de preceitos que descreve a Ordem Econômica, consagrando um sistema econômico a ser adotado pelo Estado ${ }^{56}$. Eros Grau considera constituição econômica e Ordem Econômica como sinônimos em sede da ADI $\mathrm{n}^{\mathbf{o}}$ 1.950/SP, pois a constituição econômica, parcela do ordenamento jurídico - mundo do dever ser compreende um sistema de normas que determinará o modo de produção econômica.

No seio das constituições liberais, apesar de não se verificar uma normatização econômica expressa no aspecto formal, denotava-se uma constituição econômica em sentido material.

\footnotetext{
${ }^{55}$ MENDES, 2008, p.1.

${ }^{56}$ GRAU, 2010, p.79.
} 
Gilmar $\mathrm{MENDES}^{57}$ ensina que, mesmo nas constituições liberais, havia constituição econômica em razão da existência de diversos institutos constitucionais que repercutiam na órbita econômica, v.g., o direito de propriedade, da liberdade de comércio e indústria, entre outros dispositivos que versavam sobre direito privado e comercial.

Afinal, as constituições liberais, ao se calarem - omissão que refletia a própria natureza do Estado Liberal, abstencionista, e implicava na não regulação econômica - disseram muito.

Ao desconhecerem institutos para regular a atividade econômica, essas cartas políticas, em seu silêncio, deram significado jurídico e econômico à ordem econômica.

De modo que a falta de regulação garantia plena liberdade para o exercício do gozo da propriedade, a livre concorrência e a liberdade contratual. Denota-se a ausência de mera constituição econômica formal, todavia, é inegável a presença de institutos que configuram uma constituição econômica material.

$\mathrm{O}$ próprio modelo contratual à época do Estado Liberal refletia a política econômica de não intervenção, a fím de garantir a manutenção das estruturas de poder econômico, sem a mínima preocupação com a repercussão social dos institutos de direito civil.

Foi nesse período que se consagraram de forma absoluta os princípios contratuais clássicos, como o da autonomia da vontade, que preceitua a liberdade de contratação segundo a vontade individual das partes; o da obrigatoriedade, que defende a ideia de contrato como lei entre as partes, não cabendo a ninguém obstar seu adimplemento (pacta sunt servanda); e o da relatividade, este enunciava que o contrato só geraria efeitos entre os contratantes, exprimido pela locução latina "res inter alios acta neque prodest", e que obviamente desconhecia a repercussão social do contrato.

O fato econômico tinha importância apenas indireta no âmbito do Estado Liberal, as relações econômicas se confundiam com as relações intersubjetivas comuns, como aquelas entre patrão e empregado e as do ramo empresarial.

\footnotetext{
${ }^{57}$ MENDES, 2008, p. 1354.
} 
A ausência de regulação econômica nessa fase estatal levou a um grande acirramento das características capitalistas, o que, consequentemente, provocou uma reação por parte da classe social operária, flagrantemente explorada a serviço dos interesses econômicos burgueses, dando origem à discussões de natureza social.

O exercício indiscriminado das liberdades individuais só seria contornado sob a égide de um ordenamento jurídico adequado aos fins sociais. É a partir do Estado do Bem Estar Social que se passa a corrigir as incongruências de uma legislação que enunciava o princípio da isonomia, mas apenas o defendia formalmente, olvidando-se de instituir mecanismos para efetivar a igualdade material entre os indivíduos.

Houve uma série de mudanças de paradigmas constitucionais, a fim de que o Estado interviesse minimamente para, além de garantir a proteção dos institutos econômicos - o direito de propriedade, liberdade de empresa e liberdade de trabalho - como direitos fundamentais, coibisse abusos no exercício deles, e garantisse direitos sociais.

Alguns estudiosos preferem não fazer juízo crítico da atual constituição por não haver uma perspectiva temporal que os distancie e permita uma análise mais objetiva da Carta Magna. ${ }^{58}$

Contudo, é convergente o entendimento de que a Constituição de 1988, ao eleger uma estrutura de República Federativa, busca, por meio de seus diversos dispositivos, uma sociedade justa e solidária, fundada no princípio da dignidade da pessoa humana e no Estado Democrático de Direito.

(...) considera-se democrático aquele Estado de Direito que se emprenha em assegurar aos seus cidadãos o exercício efetivo não somente dos direitos civis e políticos, mas também e sobretudo dos direitos econômicos, sociais e culturais $(\ldots)^{59}$

O Estado Democrático de Direito vai procurar conciliar os direitos econômicos e sociais, ao incorporar e superar a dicotomia dos modelos liberal e social anteriormente

\footnotetext{
${ }^{58}$ MENDES, 2008, p.179.

${ }^{59}$ MENDES, 2008, p.149.
} 
debatidas. Há uma concorrência entre a liberdade econômica típica do liberalismo, e a preocupação com o desenvolvimento social característico do Estado do Bem Estar Social.

Gilmar Mendes explica em seu Curso de Direito Constitucional ${ }^{60}$ que, além de uma forma de organização, o Estado Democrático de Direito pode ser entendido como um superconceito do qual decorrem outros, dentre eles o princípio basilar da dignidade da pessoa humana.

Todavia, o douto professor cita outros autores ${ }^{61}$, como Miguel Reale, que entendem de modo diferente, por considerarem o direito uma construção humana, cultural, que tem como justificativa a manutenção da convivência social necessária ao bem estar do homem, conforme foi explicado no primeiro capítulo. Pois, todo o ordenamento jurídico tem como fonte de existência e razão de ser o homem.

Deste modo, o princípio da dignidade da pessoa humana seria um princípio maior, supraconstitucional, sequer passível de limitações ou restrições pelo princípio da proporcionalidade.

O princípio visa proteger o ser humano, como valor em si mesmo, e garantir a ele prestações básicas de a sua existência para que aconteça de forma digna. Tamanha a importância deste princípio que o legislador o elegeu como fundamento de nossa República, a influenciar todo os dispositivos do ordenamento sujeitos à Carta Magna, inclusive as atinentes ao Direito Econômico.

A dignidade da pessoa humana é fundamento do nosso modelo de República, nos termos do artigo $1^{\circ}$, III da Constituição e fim da ordem econômica, conforme verificamos no caput do artigo 170 do texto constitucional : "A ordem econômica, fundada na valorização do trabalho humano e na livre iniciativa, tem por fim assegurar a todos existência digna".

Leonardo Vizeu FIGUEIREDO defende que, para garantir a existência digna, cabe ao Estado, direcionar a atividade econômica para que se erradique a pobreza, extinguindo as desigualdades e injustiças sociais. Deste modo, o Estado terá que realizar prestações positivas,

\footnotetext{
${ }^{60}$ MENDES, 2008, p.149.

${ }^{61}$ Idem.
} 
adotando políticas de redistribuição de rendas, favorecendo classes menos abastadas e hipossuficiente, de modo a garantir o mínimo existencial para todos. ${ }^{62}$

Ou seja, o princípio da dignidade da pessoa humana, além de garantia individual indispensável à garantia dos direitos fundamentais, é fím da ordem econômica, devendo dinamizá-la para que promova a existência digna dos indivíduos ${ }^{63}$. Do mesmo entendimento partilha o professor Eros Grau:

(...) a dignidade da pessoa humana assume a mais pronunciada relevância, visto comprometer todo o exercício da atividade econômica, em sentido amplo - e em especial, o exercício da atividade econômica em sentido estrito - com o programa de promoção da existência digna, de que, repito, todos devem gozar. Daí porque se encontram constitucionalmente empenhados na realização desse programa dessa política pública maio - tanto o setor público quanto o setor privado. Logo, o exercício de qualquer parcela da atividade econômica de modo não adequado àquela promoção expressará violação do princípio duplamente contemplado na Constituição. ${ }^{64}$

Influenciada por esse princípio, a Constituição de 1988 elege uma economia de mercado, capitalista, organizada por um processo econômico liberal, que só admite intervenções para evitar abusos e preservar a livre concorrência.

Entretanto, não se identifica com o liberalismo clássico, pois o Estado defendia que a atividade econômica deveria ser exercida segundo a justiça social, fundada nos valores do trabalho humano com o objetivo de assegurar a todos existência digna, e observados determinados princípios, nos termo do artigo 170 da Carta Magna ${ }^{65}$.

Logo, a estrutura da Constituição de 1988, no que tange a Ordem Econômica, pode ser classificada como diretiva, pois estabelece fins, diretrizes e programas a serem atingidos pelo Estado e pela sociedade em geral, além de estabelecer um conjunto normativo de ação que

\footnotetext{
${ }^{62}$ FIGUEIREDO, 2011, p.55-56.

${ }^{63}$ GRAU, 2010, p.198.

${ }^{64}$ GRAU, 2010, p.199.
} 
observa e intenta realizar os objetivos e fundamentos de nosso Estado Democrático de Direito elencados nos artigos $1^{\circ}$ e $3^{\circ}$ da Carta Magna. ${ }^{6667}$

Que a Constituição de 1988 é uma Constituição dirigente, isso é inquestionável. $\mathrm{O}$ conjunto de diretrizes, programas e fins que enuncia, a serem pelo Estado e pela sociedade realizados, a ela confere o caráter de plano global normativo, do Estado e da sociedade. O seu art.170 prospera, evidenciadamente, no sentido de implantar uma nova ordem econômica. ${ }^{68}$

\subsection{Princípios Constitucionais}

É da maior importância para a interpretação e aplicação do direito, especialmente na seara constitucional, o conhecimento dos princípios. A distinção de princípios e regras não é a finalidade do presente trabalho, contudo faz se necessária uma descrição mínima dos institutos.

Ambos, regras e princípios, são espécies de normas jurídicas de obediência obrigatória. Várias distinções podem ser feitas entre eles, Marcel Stati ${ }^{69}$ afirma que os princípios são menos precisos que as regras, têm estrutura mais geral e abstrata. Uma das distinções de

\footnotetext{
${ }^{66}$ Ação Direta de Inconstitucionalidade $n^{0} 1.950 / \mathrm{SP}$, Relator Ministro Eros Grau.

${ }^{67}$ Art. $1^{\text {o }}$ A República Federativa do Brasil, formada pela união indissolúvel dos Estados e Municípios e do Distrito Federal, constitui-se em Estado Democrático de Direito e tem como fundamentos:

I - a soberania;

II - a cidadania;

III - a dignidade da pessoa humana;

IV - os valores sociais do trabalho e da livre iniciativa;

V - o pluralismo político.

(...)

Art. $3^{\circ}$ Constituem objetivos fundamentais da República Federativa do Brasil:

I - construir uma sociedade livre, justa e solidária;

II - garantir o desenvolvimento nacional;

III - erradicar a pobreza e a marginalização e reduzir as desigualdades sociais e regionais;

IV - promover o bem de todos, sem preconceitos de origem, raça, sexo, cor, idade e quaisquer outras formas de discriminação.

${ }^{68}$ GRAU, 2010, p.174.

${ }^{69}$ STATI, 1927, p. 56.
} 
maior prestígio é aquela feita por Ronald Dworkin, que destaca a particularidade na aplicação de um e de outra. O professor Gilmar Mendes, de modo prático, lança luz sobre essa aplicação:

Daí se dizer que na aplicação aos casos ocorrentes, as regras - disjuntivamente valem ou não valem, incidem ou não incidem, umas afastando ou anulando as outras, sempre que para uma mesma situação de fato existam consequências jurídicas antinômicas ou reciprocamente excludentes (...) o aplicador do direito é obrigado a disputar até descobrir e/ou eleger as normas que levará em conta para decidir as causas ou controvérsias submetidas à sua apreciação. ${ }^{70}$

Dessarte, conclui Humberto Ávila, "o problema que surge na aplicação dos princípios reside muito mais em saber qual deles será aplicado e qual a relação que mantêm entre si”. (...) não se trata da primazia de um princípio sobre outro, mas apenas inaplicabilidade do princípio eventualmente afastado, funcionando como suposto de fato da regra de decisão - que, então, necessariamente, se formula - as circunstâncias do caso e, como sua consequência jurídica, a que se extrai do princípio de maior peso.

É que, diferentemente das regras de direito, os princípios jurídicos não se apresentam como imperativos categóricos, mandatos definitivos nem ordenações de vigência diretamente emanados do legislador, antes apenas enunciam motivos para que o seu aplicador se decida neste ou naquele sentido. ${ }^{71}$

Os princípios, normas mais gerais e abstratas, são fundamentos das regras, são a ratio das regras, ocupando grau hierárquico superior. Em razão dessa superioridade hierárquica de fonte e por sua natureza estruturante do Estado Democrático de Direito, os preceitos são normas de natureza fundamental para o ordenamento jurídico, devendo as regras se submeterem a eles. $^{72}$

É que cada direito não é mero agregado de normas, porém um conjunto dotado de unidade e coerência - unidade e coerência que repousam precisamente sobre os seus (dele $=$ de um determinado direito) princípios. Daí a ênfase que imprimiu à afirmação de que são normas jurídicas os princípios, elementos internos ao sistema; isto é, estão nele integrados e inseridos

Por isso a interpretação da Constituição é denominada pela força dos princípios. ${ }^{73}$

Assim sendo, dado o valor dos preceitos, é imperioso que se faça uma análise de alguns de seus principais princípios para melhor compreensão da Ordem Jurídica estabelecida,

\footnotetext{
${ }^{70}$ MENDES, 2008, p.32.

${ }^{71}$ MENDES, 2008, p.33-34.

${ }^{72}$ MENDES, 2008, p.39.

${ }^{73}$ GRAU, 2010, p. 165 .
} 
tendo em vista que a Constituição de 1988 é marcadamente principiológica e, consequentemente, programática.

Portanto, faz-se mister o exame de alguns dos princípios gerais que condicionam a atividade econômica, dentre eles, alguns exercem maior impacto sobre a questão da intervenção econômica e devem ser obrigatoriamente compreendidos, quais sejam os da livre iniciativa, livre concorrência, e o da função social da propriedade, elencados nos três primeiros incisos do artigo 170 da Lei Magna.

\subsubsection{Princípio da Livre Iniciativa}

A Constituição Brasileira de 1988, manifestando o interesse da sociedade ali

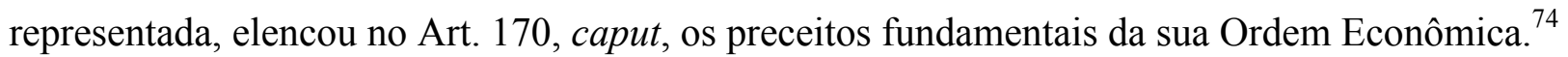

É notadamente relevante para o tema da intervenção econômica o fundamento ou princípio econômico da livre iniciativa, também conhecido como princípio da livre empresa ou da liberdade de empreender.

A Constituição confere tamanho destaque ao preceito que o elenca como fundamento do próprio Estado Democrático de Direito, ou seja, elege-o como alicerce para um Estado racional, regido pela lei, garantidor de direitos fundamentais.

Art. $1^{\circ}$ A República Federativa do Brasil, formada pela união indissolúvel dos Estados e Municípios e do Distrito Federal, constitui-se em Estado Democrático de Direito e tem como fundamentos: (...)

IV - os valores sociais do trabalho e da livre iniciativa;

\footnotetext{
${ }^{74}{ }^{74}$ Art. 170. A ordem econômica, fundada na valorização do trabalho humano e na livre iniciativa, tem por fỉm assegurar a todos existência digna, conforme os ditames da justiça social (...)
} 
Leonardo Vizeu FIGUEIREDO afirma que esse preceito fundamental, de cunho liberal, traduz-se na garantia de livre exercício da atividade econômica pelos particulares, não podendo o Estado restringi-la, salvo com a finalidade de proteger os consumidores e toda a sociedade. $^{75}$

É uma garantia jurídica aos agentes econômicos para empreender as atividades econômicas, que lhe forem mais afeitas, sem ingerência estatal. Além de proteger-se a liberdade de comércio e indústria, assegura-se a faculdade de criação e exploração de atividade econômica pelos agentes privados.

A livre iniciativa tem a finalidade de preservar a liberdade de ingressar, prosseguir e retirar-se do mercado, produzindo, fazendo circular e consumindo bens e serviços sem que haja interferências externas do Estado.

Esse princípio, resultado lógico das ideias liberais clássicas de Adam Smith, assegura aos particulares a liberdade de escolha da atividade econômica ou trabalho que desejem desempenhar, tem o escopo de resguardar a autonomia empreendedora, o que pressupunha, quando esse princípio foi inicialmente criado, uma atuação estatal negativa, de abstenção.

Porém, nem mesmo no modelo do liberalismo clássico a livre iniciativa foi exercida de forma absoluta. Apenas idealmente se defendia um Estado totalmente omisso, pois mesmo quando a livre iniciativa teria atingido seu ápice, medidas decorrentes do poder de polícia já submetiam os agentes particulares.

Eros $\mathrm{Grau}^{76}$ defende que o princípio não se resume meramente à atividade empresarial, criticando a denominação princípio da livre empresa, pois ele abrange todo o tipo de produção individual ou coletiva, afinal, existe, além da iniciativa privada, a iniciativa cooperativa ( artigo $5^{\circ}$, XVIII e artigo 174, $\S \S 3^{\circ}$ e $4^{\circ}$ da Constituição), a autogestionária, e a iniciativa pública (prevista nos artigos 173 e 177 da Constituição Federal).

\footnotetext{
${ }^{75}$ FIGUEIREDO, 2011, p.55.

${ }^{76}$ GRAU, 2010, p. 204.
} 
Sobre a relação entre a livre iniciativa e atividade estatal, cabe mencionar os seguintes trechos da obra "A Ordem Econômica na Constituição de 1988":

Afirma-se, pois, que a estrutura da ordem está centrada na atividade das pessoas e dos grupos e não na atividade do Estado. Isto não significa, porém, uma ordem 'laissez faire', posto que a livre iniciativa se conjuga com a valorização do trabalho humano. Mas, a liberdade, como fundamento, pertence a ambos. ${ }^{77}$

Não quer isso, naturalmente, significar que o serviço público seja de livre iniciativa - ou seja, de iniciativa da empresa privada - mas sim que, na sua prestação, deve, aí também, o Estado, não opor empecilho à liberdade humana, no quanto seja socialmente prezável. ${ }^{78}$

FIGUEIREDO entende que o princípio da livre iniciativa não é afeita ao Estado, pois a atuação estatal na economia se restringe às hipóteses previstas no rol taxativo da Constituição, não deixando espaço para livre atuação econômica. Por essa razão, justifica que os particulares não estão em pé de igualdade quando o Estado atua como agente econômico, havendo mera isonomia formal, o que justificaria determinadas vantagens ao Poder Público nesse caso.

Não se aplica ao Estado a liberdade de iniciativa, uma vez que este somente poderá explorar a atividade econômica dentro das previsões constitucionais, estando, por óbvio, sua atuação cerceada pela subsidiariedade.

Logo, não há que se falar que a Lei Fundamental brasileira consagra a igualdade econômica entre Poder Público e o particular em caráter absoluto, mas, apenas, em caráter formal, não havendo como se estabelecer simetria de tratamento integral entre estes.

Assim, é perfeitamente constitucional o estabelecimento de tratamento diferenciado, que não se traduzam em privilégios odiosos e injustificáveis para o Estado. $^{79}$

A despeito dessa discussão, concorda-se que o preceito fundamental é mais amplo do que comumente se percebe, ele expressa a liberdade titulada tanto pelo empresa, como por outras modalidades de trabalho. Eros Grau explica de forma elucidativa:

\footnotetext{
${ }^{77}$ GRAU, 2010, p.208.

${ }^{78}$ GRAU, 2010, p.209.

${ }^{79}$ FIGUEIREDO, 2011, p.64.
} 
Importa deixar bem vincado que a livre iniciativa é expressão de liberdade titulada não apenas pela empresa, mas também pelo trabalho. A Constituição, ao contemplar a livre iniciativa, a ela só opõe, ainda que não a exclua, a "iniciativa do Estado"; não a privilegia, assim, como bem pertinente apenas à empresa.

É que a livre iniciativa é um modo de expressão do trabalho e, por isso mesmo, corolária da valorização do trabalho, do trabalho livre - como observa Miguel Reale Júnior - em uma sociedade livre e pluralista. ${ }^{80}$

Contudo, o Estado, em defesa coletividade, tem o poder-dever de regulamentar as atividades econômicas-laborativas a fim de restringir o exercício de determinadas atividades àqueles que possuam requisitos que os capacitem ou habilitem como profissionais, de modo a garantir a prestação do serviço ou bem, no melhor interesse da sociedade. ${ }^{81}$

As restrições impostas ao princípio da livre iniciativa ocorrem justamente em razão do modelo constitucional adotado, que elegeu a dignidade do ser humano como finalidade da ordem econômica, estabelecendo limites a fim de que a atividade econômica não obstaculize a dignidade dos demais membros da sociedade.

No entanto, a fim de efetivar a dignidade da pessoa humana, as restrições ao princípio da livre iniciativa não se restringem ao combate do abuso do poder econômico. Estamos em um Estado no qual os direitos fundamentais não se limitam à mera repressão do Estado, a livre iniciativa deve ser restringida também nos casos que se almeje políticas destinadas a concretizar a justiça social e, de forma distributiva, combater as desigualdades sociais.

Entretanto, à luz das demandas sociais, essa limitação da livre iniciativa deve ser feita de forma coerente, de forma razoável e proporcional, não podendo ocorrer sistematicamente, pois o princípio da livre iniciativa é, como mencionado, fundamento do próprio Estado Democrático de Direito. Essa limitação não seria razoável, v.g., em ambiente de ampla concorrência, no qual a própria economia de mercado se encarrega de garantir acesso dos bens aos consumidores hipossuficientes ou se a limitação versar sobre bens não essenciais, v.g.,

\footnotetext{
${ }^{80}$ GRAU, 2010, p.207-208.

${ }^{81}$ FIGUEIREDO, 2011, p.55.
} 
intervenção na economia para fixar preço de revistas em quadrinhos. Já no caso de bens essenciais, aos quais não se tem amplo acesso no mercado, seria possível essa restrição.

O professor e Ministro da nossa Suprema Corte, Eros Grau, defende que o texto constitucional - em seu artigo $1^{\circ}$, IV - ao elencar como fundamento do Estado Democrático de Direito "os valores sociais do trabalho e da livre iniciativa", advoga, acertadamente, que a expressão "valores sociais" está também se referindo ao princípio da livre iniciativa.

Este em verdade enuncia, como fundamentos da República Federativa do Brasil, o valor social do trabalho e o valor social da livre iniciativa.

Isso significa que a livre iniciativa não é tomada, enquanto fundamento da República Federativa do Brasil, como expressão individualista, mas sim no quanto expressa de socialmente valioso. ${ }^{82}$

Denota-se, portanto, que a atividade econômica deve se pautar pelo interesse coletivo, social, em seus mais variados aspectos, a fim de que se respeite os objetivos do Estado Democrático de Direito, que, como explicado, tem por fito dignificar a existência do homem.

Cabe ao Estado interferir na economia por meio de um juízo de proporcionalidade e razoabilidade, e regulamentar as atividades econômicas para que sejam desempenhadas de forma a garantir os demais princípios, condizentes com o princípio da dignidade da pessoa humana, como o da livre concorrência, defesa do consumidor, defesa do meio ambiente, etc., conforme o artigo 170 da Constituição determina expressamente. ${ }^{83}$

\footnotetext{
${ }^{82}$ GRAU, 2010, p.202.

${ }^{83}$ Art. 170. A ordem econômica, fundada na valorização do trabalho humano e na livre iniciativa, tem por fim assegurar a todos existência digna, conforme os ditames da justiça social, observados os seguintes princípios:

I - soberania nacional;

II - propriedade privada;

III - função social da propriedade;

IV - livre concorrência;

$\mathrm{V}$ - defesa do consumidor;

VI - defesa do meio ambiente, inclusive mediante tratamento diferenciado conforme o impacto ambiental dos produtos e serviços e de seus processos de elaboração e prestação;

VII - redução das desigualdades regionais e sociais;

VIII - busca do pleno emprego;

IX - tratamento favorecido para as empresas de pequeno porte constituídas sob as leis brasileiras e que tenham sua sede e administração no País.
} 
Dessa forma, há garantia da livre iniciativa, contudo, ela encontra limites no interesse da coletividade, a fim de concretizar uma existência digna ao homem, seja garantindo um meio ambiente saudável, liberdade concorrencial, ou relação de consumo equilibrada.

As limitações da livre iniciativa impostas aos agentes econômicos estão adstritas ao princípio constitucional da legalidade. O Estado pode regular atividades econômicas por meio de seu poder de polícia na intenção de atender os interesses coletivos, mas essa limitação deve ser feita por lei ${ }^{84}$, conforme dispõe o parágrafo único do artigo 170 , combinado com o artigo $5^{\circ}$, II e XIII da Constituição Federal.

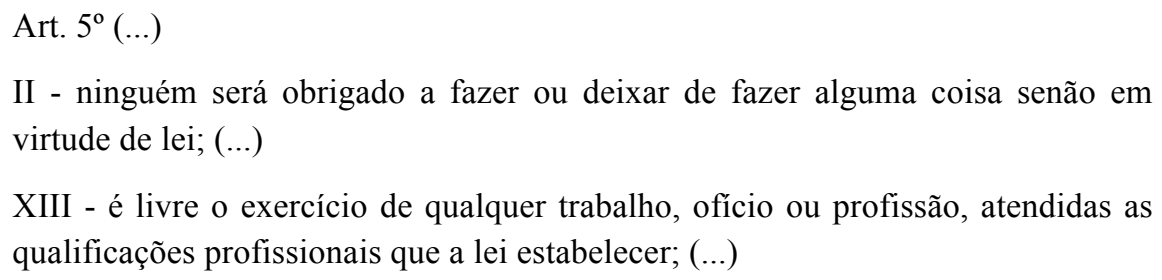

Embora um princípio de grande importância para o regular desenvolvimento da cadeia produtiva e de todo sistema econômico, ele é restringido pela própria Constituição, que prevê o monopólio de determinadas atividades econômicas pelo Estado.

Cabe unicamente ao Estado exercê-las, sem facultar o exercício da livre iniciativa aos particulares, restringindo-a nesses casos, dada a relevância dessas atividades econômicas para a coletividade e economia nacional:

Art. 177. Constituem monopólio da União:

I - a pesquisa e a lavra das jazidas de petróleo e gás natural e outros hidrocarbonetos fluidos;

II - a refinação do petróleo nacional ou estrangeiro;

${ }^{84}$ GRAU, 2010, p.206. 
III - a importação e exportação dos produtos e derivados básicos resultantes das atividades previstas nos incisos anteriores;

IV - o transporte marítimo do petróleo bruto de origem nacional ou de derivados básicos de petróleo produzidos no País, bem assim o transporte, por meio de conduto, de petróleo bruto, seus derivados e gás natural de qualquer origem;

\subsubsection{Princípio da Livre Concorrência}

Nossa Lei Fundamental elenca o princípio da livre concorrência em seu art. 170, IV ao lado dos demais princípios da ordem econômica.

Fernando Herren Aguillar ${ }^{85}$ afirma que o princípio da livre iniciativa vai delimitar a atuação dos agentes econômicos frente à intervenção do Estado, e a fará no interesse da coletividade, como mencionado.

Entretanto, a liberdade econômica, princípio implícito em nossa Carta Magna que compreende a liberdade no ciclo econômico (produção, circulação/distribuição e consumo), não se resume à livre iniciativa. A liberdade econômica é corolário da livre iniciativa, mas abrange também a liberdade de concorrência, ou seja, a livre disputa de mercados. ${ }^{86}$

Aguillar defende que quando a liberdade de empreender é ameaçada ou obstaculizada, não por intromissão estatal, mas por conta de outros agentes econômicos privados, há igual violação da livre inciativa. Nesse caso, o Estado é convocado a intervir de forma positiva para garanti-la.

A ingerência estatal se afigura indispensável em razão do princípio da livre concorrência, que tem como objetivo reprimir o abuso do direito de livremente empreender.

\footnotetext{
${ }^{85}$ AGUILLAR, 2009, p. 258.

${ }^{86}$ FIGUEIREDO, 2011, p.63.
} 
Quer dizer que o preceito da livre concorrência tem a finalidade de prevenir a violação da livre iniciativa. Intenciona combater a atuação de agentes privados que, no exercício da sua liberdade iniciativa, ao usufruírem dela de modo vicioso e descomedido, quando a exercerem de forma corrompida, abusando de seu direito de livre empreender, consequentemente, inviabilizar-se-á a própria liberdade de empreender dos demais agentes econômicos.

A livre concorrência não é uma liberdade oponível diretamente ao Estado, e sim aos particulares que exercem sua atividade econômica em caráter abusivo. Logo, pressupõe atuação estatal positiva para coibir esses abusos, cerceando, em certa medida, a liberdade do agente econômico que não se portou apropriadamente.

Defende-se, ${ }^{87}$ por outro aspecto, que o combate às práticas abusivas decorre do princípio constitucional da repressão aos abusos do poder econômico, que faz parte e decorre do preceito da livre concorrência, e não propriamente deste último princípio, nos termos do art. 173, $\S 4^{\circ}$ da Constituição Federal ${ }^{88}$.

Eros $\mathrm{Grau}^{89}$, em definição valorosa, afirma que a livre concorrência modernamente, preza por um comportamento mercadológico competitivo, que admite gradações de pluralidade e fluidez. A competitividade é o objeto de proteção do princípio, e para que ela ocorra, deve haver uma "descentralização de coordenação como base da formação dos preços, o que supõe livre iniciativa e apropriação privada dos bens de produção" ${ }^{90}$.

O princípio garante o acesso isonômico ao poder econômico, combatendo sua concentração e garantindo oportunidades iguais aos agentes econômicos. Assim sendo, deve garantir uma moderação entre grandes e pequenos agentes econômicos a fim de atingir uma sociedade mais equilibrada. ${ }^{91}$

\footnotetext{
${ }^{87}$ GRAU, 2010, p. 211.

${ }^{88}$ Art. 173. (...)

$\S 4^{\circ}$ - A lei reprimirá o abuso do poder econômico que vise à dominação dos mercados, à eliminação da concorrência e ao aumento arbitrário dos lucros.

${ }^{89}$ GRAU, 2010, p.212

${ }^{90}$ Idem.

${ }^{91}$ Idem.
} 
Desta feita, a livre concorrência é, além de interesse evidente para os agentes econômicos, espécie de tutela do consumidor. Afinal, a competitividade do mercado proporcionará acirramento da busca por mercado e, consequentemente, menores preços e produtos de melhor qualidade, beneficiando os consumidores.

Uma vez mais denota-se a proteção ao interesse coletivo e de consecução da dignidade da pessoa humana, e não apenas a proteção dos interesses individuais dos agentes privados que atuem na economia.

Do mesmo modo entende o Supremo Tribunal Federal, que julgou demanda que versava sobre um embate entre o princípio da livre iniciativa e da livre concorrência face aos da defesa do consumidor e o da redução das desigualdades sociais. Considerou-se, ponderando o interesse individual e o interesse coletivo, constitucional atividade legislativa estadual que regula a política de preços de bens e serviços, considerando abuso do poder econômico quando há aumento arbitrário dos preços objetivando lucro.

EMENTA: - Ação direta de inconstitucionalidade. Lei 8.039, de 30 de maio de 1990, que dispõe sobre critérios de reajuste das mensalidades escolares e da outras providencias. - Em face da atual Constituição, para conciliar o fundamento da livre iniciativa e do princípio da livre concorrência com os da defesa do consumidor e da redução das desigualdades sociais, em conformidade com os ditames da justiça social, pode o Estado, por via legislativa, regular a politica de preços de bens e de serviços, abusivo que e o poder econômico que visa ao aumento arbitrário dos lucros. - Não e, pois, inconstitucional a Lei 8.039, de 30 de maio de 1990, pelo só fato de ela dispor sobre critérios de reajuste das mensalidades das escolas particulares. - Exame das inconstitucionalidades alegadas com relação a cada um dos artigos da mencionada Lei. Ofensa ao princípio da irretroatividade com relação a expressão "marco" contida no paragrafo 5. do artigo 2. da referida Lei. Interpretação conforme a Constituição aplicada ao "caput" do artigo 2., ao paragrafo 5. desse mesmo artigo e ao artigo 4., todos da Lei em causa. Ação que se julga procedente em parte, para declarar a inconstitucionalidade da expressão "marco" contida no paragrafo 5. do artigo 2. da Lei no 8.039/90, e, parcialmente, o "caput" e o paragrafo 2. do artigo 2., bem como o artigo 4. os três em todos os sentidos que não aquele segundo o qual de sua aplicação estão ressalvadas as hipóteses em que, no caso concreto, ocorra direito adquirido, ato jurídico perfeito e coisa julgada. (STF. ADI 319/DF, Relator: Min. MOREIRA ALVES, Tribunal Pleno, julgado em 03/03/1993, DJ $30 / 04 / 1993)^{92}$

\footnotetext{
${ }^{92} \mathrm{ADI} \mathrm{n}^{\mathrm{o}} 319 / \mathrm{DF}$
} 
Vale ressaltar que a Lei $\mathrm{n}^{\mathrm{o}} 8.884 / 94$, criada para prevenir e repreender as infrações contra Ordem Econômica, é o instrumento hábil que materializa e dá concreção ao princípio da livre concorrência, bem como aos da livre iniciativa, da função social da propriedade, da defesa dos consumidores e da repressão ao abuso do poder econômico. Transcrevo o artigo $1^{\circ}$, que versa sobre a finalidade da lei, com atenção especial ao seu parágrafo único.

Art. $1^{\circ}$ Esta lei dispõe sobre a prevenção e a repressão às infrações contra a ordem econômica, orientada pelos ditames constitucionais de liberdade de iniciativa, livre concorrência, função social da propriedade, defesa dos consumidores e repressão ao abuso do poder econômico.

Parágrafo único. A coletividade é a titular dos bens jurídicos protegidos por esta lei. (grifo próprio) ${ }^{93}$

Tutela-se ainda o princípio da livre concorrência por meio da Lei no 8.137/90, que regula matéria penal relativa à concorrência e à Ordem Econômica. Daí verifica-se a importância que o legislador elegeu à proteção da Ordem Econômica, ao garantir a tutela penal, considerada a ultima ratio, exercida para proteger somente os bens jurídicos mais caros à sociedade.

Art. $4^{\circ}$ Constitui crime contra a ordem econômica:

I - abusar do poder econômico, dominando o mercado ou eliminando, total ou parcialmente, a concorrência mediante: (...)

II - formar acordo, convênio, ajuste ou aliança entre ofertantes, visando:

a) à fixação artificial de preços ou quantidades vendidas ou produzidas; (...)

III - discriminar preços de bens ou de prestação de serviços por ajustes ou acordo de grupo econômico, com o fím de estabelecer monopólio, ou de eliminar, total ou parcialmente, a concorrência;

IV - açambarcar, sonegar, destruir ou inutilizar bens de produção ou de consumo, com o fim de estabelecer monopólio ou de eliminar, total ou parcialmente, a concorrência;

V - provocar oscilação de preços em detrimento de empresa concorrente ou vendedor de matéria-prima, mediante ajuste ou acordo, ou por outro meio fraudulento;

${ }^{93}$ Lei $8.884 / 90$ 
VI - vender mercadorias abaixo do preço de custo, com o fim de impedir a concorrência;

VII - elevar sem justa causa o preço de bem ou serviço, valendo-se de posição dominante no mercado.

Pena - reclusão, de 2 (dois) a 5 (cinco) anos, ou multa. (grifo próprio)

Reafirma-se, portanto, o posicionamento feito ao longo deste trabalho, de que a

Ordem Econômica, parcela da ordem jurídica, produto da atividade do Estado, não é mero interesse individual dos agentes privados que exerçam atividades econômicas, sua importância reside no interesse coletivo de concretização dos fundamentos do nosso Estado Democrático de Direito, destacando-se o princípio da dignidade da pessoa humana.

\subsubsection{Princípio da Função Social da Propriedade}

Nossa Constituição garantiu o direito de propriedade em mais de um dispositivo, disciplinando-o e confirmando-o, principalmente no artigo $5^{\mathrm{o}}$, entre os incisos XXII a XXXI. $^{94}$

\footnotetext{
${ }^{94}$ Art. $5^{\circ}$ Todos são iguais perante a lei, sem distinção de qualquer natureza, garantindo-se aos brasileiros e aos estrangeiros residentes no País a inviolabilidade do direito à vida, à liberdade, à igualdade, à segurança e à propriedade, nos termos seguintes: (...) XXII - é garantido o direito de propriedade; XXIII - a propriedade atenderá a sua função social; XXIV - a lei estabelecerá o procedimento para desapropriação por necessidade ou utilidade pública, ou por interesse social, mediante justa e prévia indenização em dinheiro, ressalvados os casos previstos nesta Constituição; XXV - no caso de iminente perigo público, a autoridade competente poderá usar de propriedade particular, assegurada ao proprietário indenização ulterior, se houver dano;

XXVI - a pequena propriedade rural, assim definida em lei, desde que trabalhada pela família, não será objeto de penhora para pagamento de débitos decorrentes de sua atividade produtiva, dispondo a lei sobre os meios de financiar o seu desenvolvimento;

XXVII - aos autores pertence o direito exclusivo de utilização, publicação ou reprodução de suas obras, transmissível aos herdeiros pelo tempo que a lei fixar;

XXVIII - são assegurados, nos termos da lei:

a) a proteção às participações individuais em obras coletivas e à reprodução da imagem e voz humanas, inclusive nas atividades desportivas;

b) o direito de fiscalização do aproveitamento econômico das obras que criarem ou de que participarem aos criadores, aos intérpretes e às respectivas representações sindicais e associativas;
} 
Como explicado no início do trabalho, para Hobbes, teórico contratualista que goza de prestígio histórico por suas teorias, a segurança da propriedade é um dos motivos que levam os homens a se associarem e se submeterem ao poder do Estado. Demonstra-se que, desde o Ancien Régime, época em que o autor viveu, a propriedade já era considerada como direito de vital importância ao homem, e capaz de justificar a submissão ao Estado para preservá-la.

Pois, é o próprio direito, imposto pelo Estado, que criará a figura da propriedade, é o ordenamento jurídico que define a propriedade, que converte o mero ter de fato a coisa, em uma diversidade de direitos inerentes à propriedade. Enfim, a propriedade é núcleo essencial para a subsistência humana, é primordialmente por meio dela, por meio dos bens, que se suprem as carências materiais necessárias ao sustento do homem, bem como se efetiva a dignidade da pessoa humana.

Nesse passo, o artigo 170 da Constituição de 1988 enuncia em seus incisos II e III, respectivamente, a propriedade privada e sua função social como princípios a serem observados pela Ordem Econômica.

A atual sistemática jurídica da nossa Carta Magna, no que tange o direito de propriedade, não protege, como outrora, apenas a propriedade privada, entendida como bens móveis ou imóveis, e sim toda uma gama de relações patrimoniais.

Entende-se ampliativamente a proteção constitucional da propriedade, estendendo sua qualidade de direito fundamental às demais relações de índole patrimonial, como as hipotecas, depósitos bancários, pretensões salariais, direitos de patente e marca, etc. ${ }^{95}$

A propriedade não constitui uma instituição única, mas o conjunto de várias instituições, relacionadas a diversos tipos de bens. (...) Temo-lo, assim, em inúmeras formas, subjetivas e objetivas, conteúdos normativos diversos sendo

XXIX - a lei assegurará aos autores de inventos industriais privilégio temporário para sua utilização, bem como proteção às criações industriais, à propriedade das marcas, aos nomes de empresas e a outros signos distintivos, tendo em vista o interesse social e o desenvolvimento tecnológico e econômico do País;

XXX - é garantido o direito de herança;

XXXI - a sucessão de bens de estrangeiros situados no País será regulada pela lei brasileira em benefício do cônjuge ou dos filhos brasileiros, sempre que não lhes seja mais favorável a lei pessoal do "de cujus";

${ }^{95}$ MENDES, 2008, p.425. 
desenhados para aplicação a cada uma delas, o que importa no reconhecimento, pelo direito positivo, da multiplicidade da propriedade. ${ }^{96}$

Assim como o restante dos direitos fundamentais, o direito de propriedade deve compatibilizar o ambiente de liberdade individual com o interesse da comunidade. ${ }^{97}$ Faz-se mister um criterioso sopesamento dos interesses individuais e coletivos quando da aplicação desse direito, seja na seara judiciária, executiva ou legislativa.

Deve-se ponderar o direito de propriedade e sua utilidade privada em face do intuito de se alcançar uma sociedade justa, na qual a propriedade tenha função social. Contudo, sem abandonar a proteção essencial que o direito de propriedade confere ao cidadão, não podendo a propriedade privada estar sujeita de forma irrestrita ao interesse estatal ou da coletividade.

A função social da propriedade é um princípio que vai atribuir conteúdo social à noção de propriedade privada, pois esta foi fundamentalmente concebida como direito individual, de função individual, seu caráter social é fenômeno que se liga às transformações que se seguiram ao Estado Liberal, como já explicadas.

O princípio vai afetar o uso da propriedade, que ocorrer de modo compatível com a sua função social, ou seja, levando se em consideração demais princípios constitucionais garantes, como o do meio ambiente saudável ( não exerce sua função social aquela propriedade que polui o meio ambiente), direito à saúde (a propriedade contraria a funcionalidade social quando põe em risco a saúde dos demais, v.g., um casa noturna que impede os vizinhos de dormirem), etc.

Ademais, não é só o uso inadequado que não coaduna com o princípio da função social, a propriedade que não é utilizada, servindo meramente para fins especulativos, ou acumulação da propriedade sem a utilização do fim a que ela se propõe, também são casos que

\footnotetext{
${ }^{96}$ GRAU, 2010, p.241.

${ }^{97}$ MENDES, 2008, p.439.
} 
ferem o princípio da função social. A propriedade que tem função social é aquela justificada pelos seus fins, serviços e função.

A Constituição Federal tutela tanto o direito fundamental da propriedade, bem como a sua função social, o que enseja uma ponderação entre ambas garantias, que se tomadas em caráter absoluto acabariam por se excluírem, o que não se coaduna com a sistemática constitucional.

Como não foi estabelecida constitucionalmente uma hierarquia entre a garantia da propriedade e sua função social, cabe ao intérprete da norma constitucional, ponderar a tensão entre os dois, mediante análise do caso in concreto, utilizando-se de um juízo de razoabilidade e proporcionalidade buscando-se uma decisão justa (intencionando a justiça em sentido material), em medida que atenda aos interesses do Estado Democrático de Direito. ${ }^{98}$

Cabe ressaltar a questão da função social dos contratos, alguns entendem que o princípio da liberdade de contratar decorre da livre iniciativa, para Eros Grau: "a liberdade de contratar não é senão um corolário da propriedade privada dos bens de produção". ${ }^{99}$

Como resultado da função social da propriedade, há uma mudança significativa na sistemática contratual, os contratos também assumem função social, abandona-se, portanto, o amplo poder de autorregularão contratual típico do Estado Liberal, e adota-se, como no nosso ordenamento, o dirigismo contratual.

O contrato é um dos reflexos da concepção neoliberal de Estado Regulador assente em nossa Constituição. Eles deixaram de se sujeitar a mera vontade das partes e passaram a se condicionar à valores sociais constitucionais. Eros Grau aponta a que os contatos são considerados "verdadeiros instrumentos de política econômica" que não se limitam ao âmbito do Direito Civil, servindo ao desenvolvimento e justiça social ${ }^{100}$

\footnotetext{
${ }^{98}$ MENDES, 2008, p.1357.

${ }^{99}$ GRAU, 2010, p. 92.

${ }^{100}$ GRAU, 2010, p.93
} 
Atualmente, as disposições contratuais tem que se ater à justiça social, à solidariedade, à dignidade da pessoa humana (dos contratantes e terceiros), à igualdade substancial e ao conteúdo. Devem, do mesmo modo que a propriedade, preservar os interesses econômicos da sociedade, ambientais, trabalhistas, etc.

Há uma relativização dos princípios contratuais clássicos: autonomia, obrigatoriedade e relatividade, etc. em face de dois novos princípios, o da função social dos contratos e o da boa-fé objetiva. Portanto, abandona-se o modelo com primazia na vontade e adota-se os limites da justiça social, estabelecendo limites negativos e positivos à autonomia privada.

O contrato não é mais interesse meramente individual das partes, ele assume caráter metaindividual, de interesse social. Afinal, os contratos têm efeitos transcendentes, repercutem na coletividade.

Passaram a ser instrumento de promoção das questões existenciais da pessoa humana, concretizando o princípio da dignidade da pessoa humana.

Enunciado 23 - Art. 421: a função social do contrato, prevista no art. 421 do novo Código Civil, não elimina o princípio da autonomia contratual, mas atenua ou reduz o alcance desse princípio quando presentes interesses metaindividuais ou interesse individual relativo à dignidade da pessoa humana. ${ }^{101}$

Outra faceta do princípio da função social da propriedade é a função social da empresa. A função social da propriedade abrange os bens destinados à produção, quais sejam as propriedades voltadas para atividade econômica. Logo, esses bens, sujeitos à função social, por estarem vinculados ao regime da empresa, essa, consequentemente, também deve estar adstrita à função social.

Desta feita, pode e deve o Estado intervir na economia ativamente a fim de efetivar a função social da propriedade. Do mesmo modo considerou o Supremo Tribunal no julgamento da $\mathrm{ADI} \mathrm{n}^{\mathrm{o}}$ 1.950/SP, que considerou constitucional lei que institui meia entrada para estudantes no cinema, dai demonstrando que prevaleceu a interpretação da função social da

${ }^{101}$ Enunciado 23 da $1^{\text {a }}$ Jornada de Direito Civil 
propriedade (no caso a função social estaria ligada ao direito à cultura e educação), e não o direito de propriedade em caráter absoluto.

EMENTA: AÇÃO DIRETA DE INCONSTITUCIONALIDADE. LEI N. 7.844/92, DO ESTADO DE SÃO PAULO. MEIA ENTRADA ASSEGURADA AOS ESTUDANTES REGULARMENTE MATRICULADOS EM ESTABELECIMENTOS DE ENSINO. INGRESSO EM CASAS DE DIVERSÃO, ESPORTE, CULTURA E LAZER. COMPETÊNCIA CONCORRENTE ENTRE A UNIÃO, ESTADOS-MEMBROS E O DISTRITO FEDERAL PARA LEGISLAR SOBRE DIREITO ECONÔMICO. CONSTITUCIONALIDADE. LIVRE INICIATIVA E ORDEM ECONÔMICA. MERCADO. INTERVENÇÃO DO ESTADO NA ECONOMIA. ARTIGOS $1^{\circ}$, $3^{\circ}, 170,205,208,215$ e $217, \S 3^{\circ}$, DA CONSTITUIÇÃO DO BRASIL. 1 . É certo que a ordem econômica na Constituição de 1.988 define opção por um sistema no qual joga um papel primordial a livre iniciativa. Essa circunstância não legitima, no entanto, a assertiva de que o Estado só intervirá na economia em situações excepcionais. 2. Mais do que simples instrumento de governo, a nossa Constituição enuncia diretrizes, programas e fins a serem realizados pelo Estado e pela sociedade. Postula um plano de ação global normativo para o Estado e para a sociedade, informado pelos preceitos veiculados pelos seus artigos $1^{\circ}, 3^{\circ}$ e 170.3 . A livre iniciativa é expressão de liberdade titulada não apenas pela empresa, mas também pelo trabalho. Por isso a Constituição, ao contemplá-la, cogita também da "iniciativa do Estado"; não a privilegia, portanto, como bem pertinente apenas à empresa. 4. Se de um lado a Constituição assegura a livre iniciativa, de outro determina ao Estado a adoção de todas as providências tendentes a garantir o efetivo exercício do direito à educação, à cultura e ao desporto [artigos 23, inciso V, 205, 208, 215 e $217 \S 3^{\circ}$, da Constituição]. Na composição entre esses princípios e regras há de ser preservado o interesse da coletividade, interesse público primário. 5. O direito ao acesso à cultura, ao esporte e ao lazer, são meios de complementar a formação dos estudantes. 6. Ação direta de inconstitucionalidade julgada improcedente. ADI 1950, Relator(a): Min. EROS GRAU, Tribunal Pleno, julgado em 03/11/2005, DJ 02-06-2006. ${ }^{102}$

Verificou-se o caráter social na efetivação de outros direitos igualmente caros à

Carta Magna e à coletividade, nesse caso, necessários ao desenvolvimento social por meio do acesso à cultura, lazer e esporte.

${ }^{102} \mathrm{ADI} \mathrm{n}^{\mathrm{o}} 1.950 / \mathrm{SP}$ 